\title{
Biology of Bone Sarcomas and New Therapeutic Developments
}

\author{
Hannah K. Brown ${ }^{1,5} \cdot$ Kristina Schiavone $^{1,5}$ - François Gouin ${ }^{2,3} \cdot$ Marie-Françoise Heymann ${ }^{1,4,5}$. \\ Dominique Heymann ${ }^{1,3,4,5}$ (i)
}

Received: 3 August 2017 / Accepted: 29 November 2017 / Published online: 13 December 2017

(c) The Author(s) 2017. This article is an open access publication

\begin{abstract}
Bone sarcomas are tumours belonging to the family of mesenchymal tumours and constitute a highly heterogeneous tumour group. The three main bone sarcomas are osteosarcoma, Ewing sarcoma and chondrosarcoma each subdivided in diverse histological entities. They are clinically characterised by a relatively high morbidity and mortality, especially in children and adolescents. Although these tumours are histologically, molecularly and genetically heterogeneous, they share a common involvement of the local microenvironment in their pathogenesis. This review gives a brief overview of their specificities and summarises the main therapeutic advances in the field of bone sarcoma.
\end{abstract}

Keywords Osteosarcoma - Ewing sarcoma Chondrosarcoma - Giant cell tumour of bone $\cdot$ Tumour microenvironment . Immunotherapy $\cdot$ Clinical trials

\section{Introduction}

Bone sarcomas belong to a mesenchymal tumour family originating from bone and composed by highly heterogeneous subtypes. These tumours represent $<0.2 \%$ of malignant tumours registered in the EUROCARE database, and are considered as rare cancers and orphan tumours [1]. The three main entities are osteosarcoma, Ewing sarcoma and chondrosarcoma [2-4]. Mesenchymal stem cells (MSCs) located in most of the tissues have the ability to differentiate into various mesenchymal tissues including bone and cartilage [5]. Bone marrow and the bone environment are particularly

Dominique Heymann

dominique.heymann@univ-nantes.fr

1 Department of Oncology and Metabolism, Medical School, University of Sheffield, Beech Hill Road, Sheffield S10 2RX, UK

2 European Associated Laboratory, "Sarcoma Research Unit", Faculty of Medicine, INSERM, UMR1238, INSERM, Nantes, France

3 Faculty of Medicine, University of Nantes, 44035 Nantes, France

4 Institut de Cancérologie de l'Ouest, site René Gauducheau, INSERM, UMR 1232, 44805 Saint-Herblain, France

5 European Associated Laboratory, "Sarcoma Research Unit", INSERM, Medical School, University of Sheffield, Beech Hill Road, Sheffield S10 2RX, UK rich in MSCs, which generate stromal cells thus supporting the haematopoiesis in addition to the bone maintenance [6, 7]. This process is in fact controlled by specific transcription factors expressed during the differentiation programme of MSCs, which orientate their differentiation towards determined cell lineages. Thus, the runx 2 and sox 9 master genes induce a hierarchical regulation of downstream genes modulated by MSCs and drive the differentiation of MSCs into an osteoblastic and chondroblastic lineage, respectively $[4,5]$. The present review aims to give an overview on the main characteristics of bone sarcomas with a specific focus on the most recent clinical developments.

\section{Main Biological Characteristics of Bone Sarcomas}

Bone sarcoma genesis can be explained by a conjunction between a minimum of one oncogenic event and an adequate microenvironment leading to the emergence of cancer, followed by its growth and potential migration to distant organs. Oncogenic events at the gene expression level (e.g. mutation, duplication, translocation) occurring during MSC differentiation increase the risk of their transformation to cancerous cells and result in the emergence of malignant osteoblastic or chondroblastic malignant cells. Indeed, osteosarcoma and chondrosarcoma cells express runx 2 and 
sox9 in a similar manner than their non-malignant homologues [8-11]. This expression of master genes in addition to their embryologic origin and their morphology strongly establish their close relationship with MSCs (Fig. 1). In this context, osteosarcoma cells originate from MSCs that are more or less committed to the osteoblast differentiation programme in which the oncogenic events occur. Consequently, osteosarcoma cells can express osteoblastic markers such as alkaline phosphatase, osteocalcin or bone sialoprotein and show a strong capacity to form osteoid tissue and induce the mineralisation of extracellular matrix. Chondrosarcoma cells share common features with chondrocytes and express chondrocyte markers such as type II collagen or aggrecan (Fig. 1). Because chondrosarcoma cells are cytologically and phenotypically related to chondrocytes, they are able to produce cartilaginous matrix into which malignant chondrocytes become encased. Chondrosarcoma can form benign lesions in which the Hedgehog signalling pathway (such as EXT1 and EXT2 involved in the endochondral ossification) is dysregulated and evolve into malignant entities [12-14]. While osteosarcoma and chondrosarcoma can be considered as the result of a disturbed differentiation programme of MSCs, the origin of Ewing sarcoma is more controverted. Indeed, Ewing sarcoma cells are characterised by the expression of a fusion protein resulting from a chromosomal translocation between the EWS gene on chromosome 2 and a gene of the ETS family and consequently have been initially associated with the primitive neuroectodermal family of tumours [15]. However, the main frequent

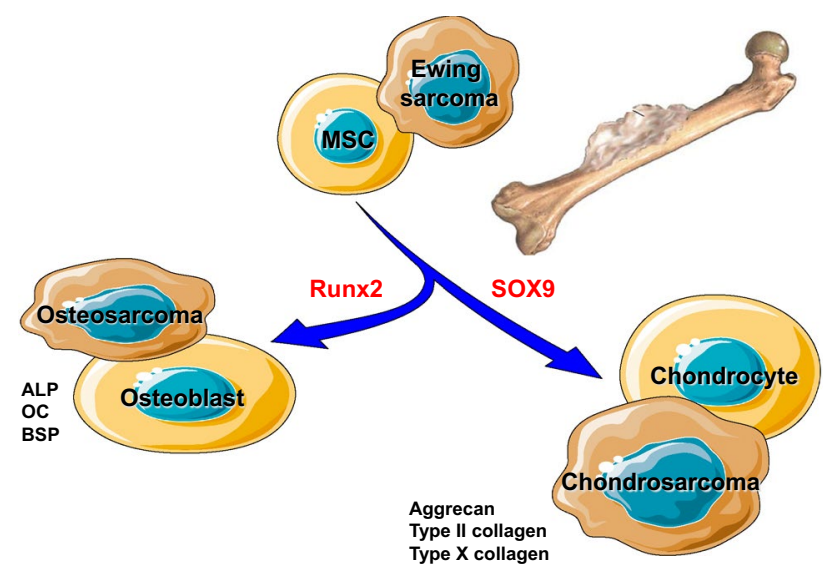

Fig. 1 Origin of bone sarcomas. Based on the current knowledge, osteosarcoma, Ewing sarcoma and chondrosarcoma share a common mesenchymal origin. According to their differentiation level and in association with oncogenic events and an adapted microenvironment their common precursor, a "mesenchymal stem cell" could be transformed into an osteosarcoma, chondrosarcoma or an Ewing sarcoma. Sox9 Sry-related high-mobility group box (Sox) transcription factor 9 related to chondrogenic differentiation, Runx2 runt-related transcription factor 2 related to osteoblastogenesis, $A L P$ alkaline phosphatase, $O C$ osteocalcin, $B S P$ bone sialoprotein location of Ewing sarcoma in bone and the functional consequence of EWS-FLil silencing in Ewing sarcoma cells fed the controversy and put a label of mesenchymal origin on Ewing sarcoma [15]. Indeed, Tirode et al. showed that the EWS-FLI1 silencing in different Ewing cell lines resulted in the differentiation of sarcoma cells into mesenchymal lineages and more particularly into adipogenic and osteogenic lineages [16]. To date, its origin remains elusive with three potential hypotheses: neural crest stem cells [17], embryonic osteochondrogenic progenitor cells [18] or MSCs [16, 19]. Numerous pre-clinical models based on in vitro approaches and in vivo investigations (e.g. rat, mouse, zebrafish) mimicking the human disease have been proposed and are currently used to study the pathogenesis of bone sarcomas and/ or for screening new drugs [20-28].

\section{Main Clinical Characteristics of Bone Sarcomas}

Osteosarcoma, Ewing sarcoma and chondrosarcoma are separated into three different clinical entities identifiable by the patient populations affected, their localisation and their biological characteristics (Table 1). Osteosarcoma is the most frequent malignant primary bone tumour with a higher incidence in adolescent and young adults. Two peaks of incidence are conventionally described: (i) a main peak at 18 years and (ii) a second peak at 60 years with poor prognosis corresponding frequently to secondary osteosarcoma developed after radiotherapy or after Paget disease of bone [2,3]. All osteosarcomas are characterised by the presence of a mineralised osteoid matrix produced by cancer cells and which results in the typical radiographic appearances called "sunburst" pattern [4, 29]. Osteosarcoma are very heterogeneous tumours (intra- and inter-tumoural heterogeneity) as revealed by the multiple histological subtypes according to the degree of cancer cell differentiation and consequently the quality of the extracellular matrix secreted (e.g. osteoblastic, chondroblastic, fibroblastic, telangiectatic osteosarcoma). The main affected areas of osteosarcoma are the metaphysis of the long bones with a preference to the proximal end of the tibia/fibula corresponding to the location of the growth plate. Genetic analyses confirmed the high heterogeneity of osteosarcoma [30-32]. Bousquet et al. identified for instance more than 80 point mutations and some deletions related to more than 80 genes [30]. Kovac et al. interestingly identified a BRCAness signature in osteosarcoma which could be exploited as a new therapeutic targeting [31]. The overall survival of osteosarcoma patients is very dependent on their metastatic status at the time of diagnosis with a survival rate for patients with localised disease of around $65 \%$ after 5 years; however, when lung 
Table 1 Characteristics of the three main bone sarcomas

\begin{tabular}{|c|c|c|c|c|c|}
\hline Tumour type & $\begin{array}{l}\text { Ratio } \\
\text { male/ } \\
\text { female }\end{array}$ & Frequency $^{\mathrm{a}}$ & Peak of incidence (years) & Principal localisations & Survival rate \\
\hline Osteosarcoma & 1.4 & $\begin{array}{l}0.2-0.3 / 100,000 / \text { year } \\
\text { (general popula- } \\
\text { tion) } \\
08-1.1 / 100,000 / \text { year } \\
\text { at age } 15-19\end{array}$ & $\begin{array}{l}\text { Main peak: } 18 \\
\text { Secondary peak: } 60\end{array}$ & $\begin{array}{l}\text { Metaphysis of long bones } \\
\text { Distal end of femur + proximal } \\
\text { end tibia/fibula }(60 \%)\end{array}$ & $\begin{array}{l}60-70 \% \text { after } 5 \text { years } \\
30 \% \text { after } 5 \text { years (with lung } \\
\text { metastases) }\end{array}$ \\
\hline Ewing sarcoma & 1.5 & $0.3 / 100,000 /$ year & 15 & $\begin{array}{l}\text { Flat bones }(60 \%) \\
\text { Metaphysis of long bones } \\
\quad(40 \%) \text { and soft tissues }\end{array}$ & $\begin{array}{l}66 \% \text { at } 5 \text { years and } 20 \% \text { at } \\
5 \text { years for poor responders }\end{array}$ \\
\hline Chondrosarcoma & 1 & $0.2 / 100,000 /$ year & 45 & $\begin{array}{l}\text { Pelvic bone, femur, proximal } \\
\text { humerus, scapula }\end{array}$ & $\begin{array}{l}50-60 \% \text { at } 10 \text { years according } \\
\text { the histological grade }\end{array}$ \\
\hline
\end{tabular}

${ }^{\text {a }}$ Source: ref [2]

metastases are detected, survival drops to $30 \%$ (Table 1). Around $10-20 \%$ of patients show clinically detectable metastases at time of diagnosis and $85-90 \%$ are located in the lungs.

Ewing sarcoma is the second main represented bone sarcoma with $0.3 / 100,000 /$ year. This bone sarcoma subtype accounts for $2 \%$ of childhood cancers, is more predominant in male than female with a sex male/female ratio around 1.5 and has a peak of incidence at 15 years. Sixty percent of Ewing sarcomas develop in flat bones and $40 \%$ affect the metaphysis of long bones (Table 1). Similar to osteosarcoma, the overall survival is also associated with the metastatic status of patients. For localised tumours, the overall survival is $50-60 \%$ at 5 years, which drops to only around $20 \%$ for metastatic sarcoma. At time of diagnosis, $20-25 \%$ of patients show clinically detectable metastases [33-35]. Although Ewing sarcoma is the most homogeneous entity among bone sarcomas, composed of undifferentiated round cancer cells characterised by CD99-, FLI1-, HNK1 - and CAV1-positive immunostaining associated with limited stromal components [36], recent work demonstrated in contrast their heterogeneity [37-40]. Previous studies highlighted only a few recurrent somatic mutations in Ewing sarcomas (TP53, STAG2, CDKN2) [38, 41, 42]. However, more recent studies by Zhang et al. used nextgeneration sequencing (Ion AmpliSeq ${ }^{\mathrm{TM}}$ Cancer Hotspot Panel v2) to identify a series of five new mutations (KDR, STK11, MLH1, KRAS and PTPN11) related to a higher proliferation index and revealing a higher tumour heterogeneity than initially suspected [37]. This heterogeneity is not restricted to the genetic patterns but can be extended to epigenetic profiles [39]. Indeed, Sheffield et al. showed heterogeneous DNA methylation profiles between different tumours, which could reflect a continuum between mesenchymal and stem cell signatures in link with the EWS-FLI1 signature [39]. In addition, the expression levels of EWS-FLi1, which are variable in a tumour tissue, have a functional impact on cell migration. EWSR1-FLi$1^{\text {high }}$ cells are characterised by high proliferation activity, while EWSR1-FLi1 ${ }^{\text {low }}$ have a marked propensity to migrate, invade and metastasise [40].

Chondrosarcoma is the third entity of bone sarcoma in term of incidence with around 0.2 new cases per 100,000 each year and similar incidence between male and female (Table 1). Similar to all bone sarcomas, several subtypes can be identified according to their histological characteristics [43-46] and are classified as low, intermediate or high grade on the basis of histopathological features [47]. Chondrosarcomas are characterised by a tumour chondrocyte-derived hyaline-like extracellular matrix, which eventually encases the cancer cells. The tumour tissue is organised in a mosaic of lobules separated by fibrous tissue. In addition, chondrosarcomas exhibit low vascularisation in contrast to osteosarcoma and Ewing sarcomas. Heterogeneity is also a hallmark of chondrosarcomas, which are associated with a complex cytogenetic signature [48, 49]. Thus, somatic mutations in isocitrate dehydrogenase (IDH)-1 or -2 are frequent (around 56\%) in central and periosteal cartilaginous tumours and absent in endochondroma [50]. In addition to mutations in $I D H 1, I D H 2, E X T$ (exostosin) and more conventional genes associated with cancer progression such as TP53 or Rb1, Tarpey et al. identified COL2A1 mutations (insertions, deletions and rearrangements) in the third cases [51]. The principal localisations of chondrosarcomas are pelvic bone, scapula and long bones (Table 1). While high-grade chondrosarcomas can be associated with metastases, these tumours are characterised by a high rate of local recurrence and consequently by a high morbidity [52, 53]. Osteosarcoma, Ewing sarcoma and chondrosarcoma are then characterised by a marked heterogeneity at the histological, genetic and epigenetic levels. 


\section{Etiology of Bone Sarcomas: The Microenvironment as the Driver of Cancer Progression}

In addition to c-fos which has been associated with osteosarcoma formation due to its contribution in osteoblast differentiation $[54,55]$, some genetic predispositions have been linked with osteosarcoma development in hereditary syndromes such as Li-Fraumeni (p53 mutation) [56], Rothmund-Thompson [57], Werner [58] or Bloom syndromes (mutations of helicase genes) [59,60], or retinoblastoma familial cancers [61]. Hereditary multiple exostoses (familial osteochondromatosis or diaphyseal aclasis) is an inherited genetic disease associated with osteochondromas and with EXT1 and EXT2 mutations [14, 62]. Even if several studies evaluated the risk of malignant transformation of multiple exostoses, the most recent study identified this risk at relatively low level $(2.7 \%)$ with the development of low-grade chondrosarcomas [63]. However in most of the cases, patients do not show any predisposition genes and bone sarcomas are sporadic cases which could be explained by a close relationship with their local microenvironment altered during the malignant transformation process [64-68]. The "seed and soil" theory proposed by Stephen Paget at the end of the nineteenth century gives a partial explanation of bone sarcoma formation [69]. At the early stage of the disease, proliferation of bone sarcoma cells in the bone environment leads to the dysregulation of the balance between osteoblasts and osteoclasts, in favour of an exacerbated osteoclast differentiation and local bone resorption. In turn, resorptive osteoclasts release pro-tumoral factors (e.g. cytokines, extracellular matrix components) initially trapped into the organic matrix of bone tissue [70]. The demonstration of this vicious cycle between osteoclasts and bone sarcoma cells has stimulated numerous pre-clinical and clinical investigations that revealed the decrease of tumour bone sarcomas after targeting of osteoclasts using anti-resorptive agents [71-75]. In addition to their anti-resorptive activities, nitrogen-containing bisphosphonates could have a direct anti-proliferative activity on cancer cells $[76,77]$. On the contrary, Endo-Munoz et al. showed the deleterious effect of osteoclastogenesis inhibition after zoledronic acid treatment which was associated with an increase of lung metastases in an osteosarcoma model [78]. The role of osteoclasts in bone sarcoma development is still unclear and osteoclasts could act as a pro-tumoral factor in the early stage of the disease due to their pro-angiogenic activity [79] and could exert the opposite role at a later stage of the disease [80].

Bone sarcoma development could be explained by the conjunction of multiple factors: (i) one or more oncogenic events from which the malignant transformation is initiated. The risks of genetic aberrations at the gene expression level (e.g. mutation, deletion, amplification) could increase with the proliferation rate of the cells of interest such as MSCs/osteoblasts during bone growth. A first mutation could lead to a chromosomal instability and consequently to the appearance of new oncogenic events [31]. (ii) A favourable microenvironment is a prerequisite for the growth of cancer cells. The differential repartition of bone sarcomas according to their subtypes are in favour of this theory. Furthermore, numerous studies demonstrated that MSCs induce pro-proliferative effects on bone sarcoma and promote osteosarcoma stemness strengthening the "seed and soil" theory [81, 82]. Local acidosis derived from the tumour growth and tumour-associated osteolysis has in return a strong impact on the stemness of MSCs [83, 84]. The bilateral dialogue established between cancer cells and their neighbours is a central aspect of bone sarcoma development. The diverse modes of communication include soluble factors (e.g. chemokines, cytokines), direct cell interactions and extracellular vesicles [64-66]. Gap junctions are intercellular channels composed of transmembrane proteins named connexons that allow direct intercellular communication between two adjacent cells. Recent data investigated at the singlecell level showed intercellular communications through gap junctions between osteosarcoma cells and various other cell types [85]. Functional gap junctions have been observed between osteosarcoma cells and MSCs depending on their differentiation levels, and between cancer cells and endothelial cells. In contrast, while all bone cells express gap junctions, no gap junction-dependent communication has been demonstrated with macrophages, osteoclasts or osteocytes [86-88]. Gap junctions are clearly involved in the tumour development and the loss of connexin43 expression in Ewing sarcoma cells favours the development of the primary tumour growth [89]. Another way of cell communication is transfer of extracellular vesicles loaded with proteins, mRNA and microRNA. Thus, it has been suggested that osteosarcoma cells are able to resist the effects of chemotherapeutic treatment such as doxorubicin by transferring exosomes carrying specific multidrug resistance factors (e.g. MDR-1, Pgp) from resistant to non-resistant cancer cells [90]. Recently, Baglio et al. described the education of MSCs by tumoursecreted extracellular vesicles [91]. These authors demonstrated the ability of osteosarcoma cells to incorporate TGF- $\beta$ into extracellular vesicles which induced production of IL-6 in MSCs. IL-6 is in turn associated with an increase of tumour growth [92]. A vicious cycle is then established between MSCs and sarcoma cells through the release of extracellular vesicles.

The bone sarcoma microenvironment is not restricted to MSCs but is a very complex and dynamic environment 


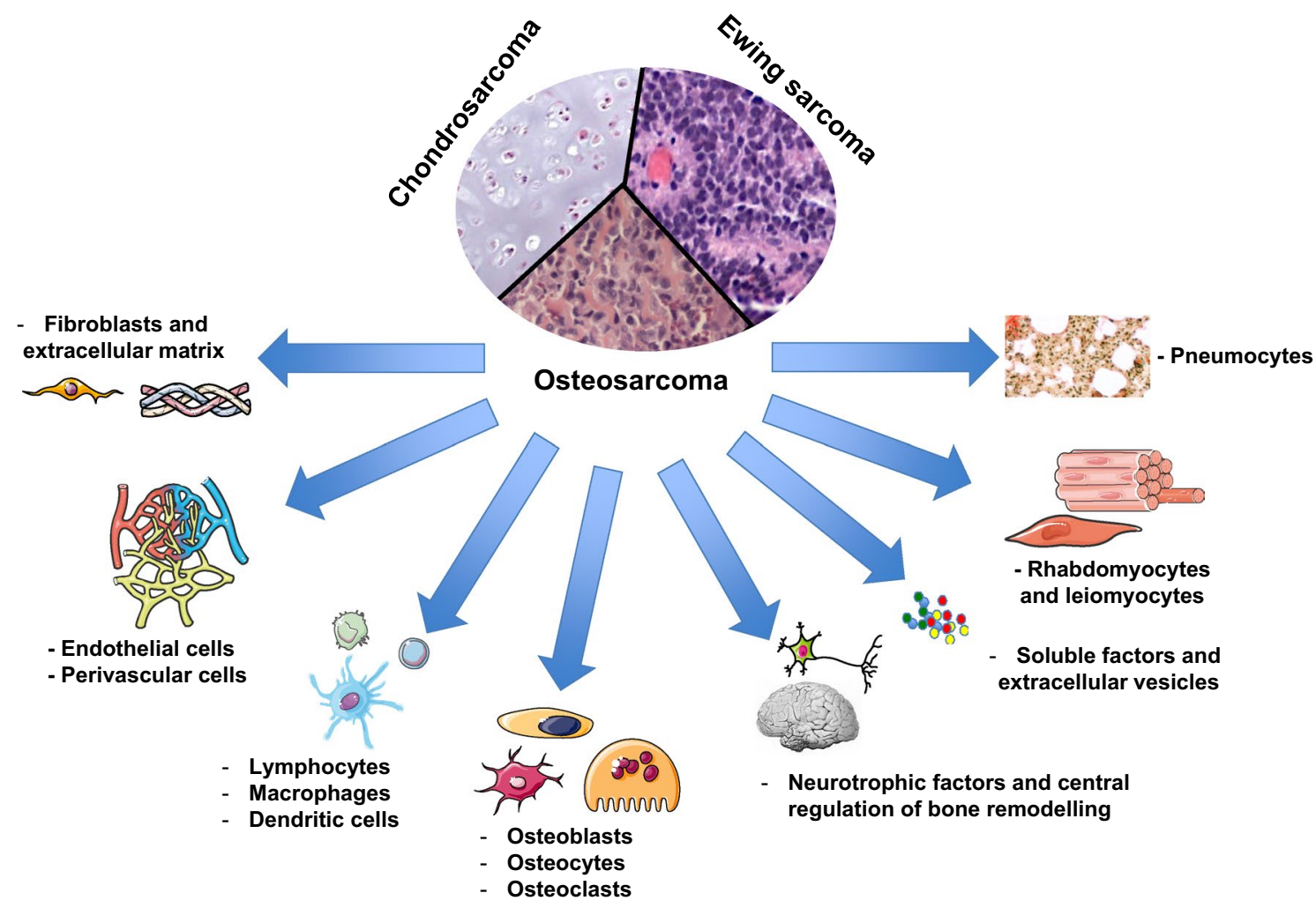

Fig. 2 The tumour microenvironment contributes to the control of bone sarcoma formation, their recurrence and associated metastatic process. The bone sarcoma microenvironment is composed of highly diversified cell populations forming specific local niches: vascular niche, immune niche, bone niche, muscular and pulmonary niches (e.g. metastatic niches), neuronal control and activity of neurotrophic factors. These various cell types establish a mutual dialogue with sar-

(Fig. 2). This environment can be described as "niches" including bone, vascular and immune niches and more specific niches such as muscles and lung parenchyma for invading and metastatic cells. Even though there is no evidence of the correlation between the vessel density and the metastatic process in bone sarcomas, endothelial cells are strongly involved in the intra/extravasation of cancer cells. Recently, new regulators including brain, neuronal network and neurotrophic factors should be added to the list. It is now well recognised that the brain can act as a master regulator of bone mass [93, 94]. Bone remodelling is indeed regulated by a rich innervation, which is the source of neurotrophic factors, hormones and neurotransmitters [95]. Released locally or into the blood stream, these soluble factors could target bone sarcoma cells $[96,97]$. The most recent evidence has been given by Punzo et al. who showed the anti-proliferative, pro-apoptotic and anti-invasive effects of endocannabinoid and endovanilloid systems in osteosarcoma [98] (Fig. 2). The bone environment is relatively specific to bone sarcomas and bone cells have been suspected to contribute to their development. Indeed, as described above, the coma cells through physical contact, the release of soluble factors or the formation of extracellular vesicles. All these communications will lead to strong alterations of the microenvironment (e.g. qualitative modifications of the extracellular matrix) and the behaviour of cancer cells, which increase their proliferation, and/or invasion/migration properties

blockade of bone resorption by bisphosphonates inhibits the tumour growth in pre-clinical models of osteosarcoma [92] and Ewing sarcoma [71] and slows down recurrent tumour progression after intralesional curettage in chondrosarcoma $[76,99]$. Unfortunately, the results of a phase III clinical trial associating conventional chemotherapy and bisphosphonate (zoledronate) do not recommend this therapeutic strategy in osteosarcoma [100]. The lack of significant efficacy can be explained by the disparity of bisphosphonate or RANKL-blocking antibody efficacy observed using the parameters of bone remodelling in different mouse strains [101]. Alternatively, bisphosphonates could modulate macrophage differentiation through complex mechanisms. Tumour-associated macrophages (TAMs) can be subdivided in two types of populations, M1-polarised macrophages considered as antitumour effectors and M2-polarised macrophages, which are defined as pro-tumour modulators due to their positive impact on the neoangiogenic process [102]. In breast cancer models, it has been shown that cancer cells secrete soluble factors modulating macrophages towards the M2 state. Zoledronate counteracts this differentiation and 
favours a cytotoxic immune response linked with the differentiation of TAMs towards the M1 subtype [103]. In mesothelioma, zoledronate impairs the polarisation of TAMs to the M2 phenotype but leads to the accumulation of immature myeloid cells, which could reduce its effects [104]. In bone sarcoma, TAMs also appeared as key effectors of the pathogenesis [105-107]. Indeed, the macrophage infiltration in osteosarcoma is correlated with metastatic suppression [105] and osteosarcoma cells dysregulate the balance of M1/M2 macrophages [106]. An abundant M2 macrophage infiltrate is consequently in favour of a metastatic profile [106]. In Ewing sarcoma, the targeting of TAMs by liposome-encapsulated clodronate that inhibits simultaneously M1 and M2 macrophages leads to a decrease of tumour growth [107]. Overall, these results demonstrate the key role of macrophages which regulate the development of bone sarcoma according to their number and M1/M2 phenotype. The role of the immune niche in bone sarcoma development is not restricted to TAMs and is also controlled by dendritic cells, tumour infiltrating lymphocytes or mast cells [108-110].

\section{Recent Therapeutic Developments}

Although current conventional treatments are relatively similar for osteosarcoma and Ewing sarcoma combining chemotherapy and surgery, the mainstay of local tumour control in chondrosarcoma is surgery with adequate margins (margins of normal tissue). Indeed, chemotherapy and radiotherapy are ineffective in the treatment of local and advanced chondrosarcoma patients. Consequently, both therapeutic approaches have limited impact in the management of these patients [111]. Unfortunately, adequate margins can only be achieved in $45-75 \%$ of patients. Inadequate margins are related to a high risk of local recurrence. Recent work validated the cryosurgery after intralesional curettage for low-grade chondrosarcoma. The technique appears safe and effective in selected patients [111]. Chemotherapy is recommended for high-risk chondrosarcoma and dedifferentiated chondrosarcoma but there is no recognised consensus defining the protocol and time schedule. The conventional therapeutic approach to osteosarcoma and Ewing sarcoma combines surgery (preoperative or neoadjuvant) and after chemotherapy (postoperative or adjuvant) and long-term (6-12 months) polychemotherapy [112-115]. The conventional cocktail used in osteosarcoma is composed by a minimum of three drugs (reference combination: doxorubicin, cisplatin, methotrexate). Ifosfamide is the fourth drug used in osteosarcoma. Radiotherapy can be used when adequate surgery is impossible and for high-risk locations (e.g. spine); however, osteosarcomas are usually considered as radioresistant. In Ewing sarcoma, chemotherapy includes vincristine, ifosfamide, doxorubicin and etoposide.
In addition, patients will receive radiotherapy since Ewing sarcoma responds relatively well to irradiation [116]. Several on-going clinical trials are studying new regimens of high doses of chemotherapy in combination with radiotherapy (Table 2). However, most conventional chemotherapy commonly results in relatively poor therapeutic responses, which has led to the development of new compounds with new therapeutic targets (Tables 2, 3; Fig. 3).

\section{Novelties in Osteosarcoma and Ewing Sarcoma}

New therapeutic approaches have been proposed and are currently on-going to improve the survival rate of osteosarcoma patients $[109,112]$. Similar strategies are now proposed for Ewing sarcoma patients.

\section{New Formulation of Chemotherapeutic Agents}

In order to reduce its cardiotoxicity, liposomal doxorubicin formulations have been designed and show similar efficacy than conventional doxorubicin [117]. Liposomal doxorubicin is currently tested in phase I in refractory paediatric solid tumours (Table 2). Liposomal formulation can also be used for the modulation of drug pharmacology profiles such as irinotecan for which its pharmacology has likely limited its clinical activity. Positive benefit of irinotecan sucrosofate liposomes was demonstrated in a xenograft model of Ewing sarcoma and is assessed in a Phase trial (NCT02013336) [118].

\section{Tyrosine Kinase Inhibitors as Multiple Target Drugs}

It is recognised that cytotoxic cancer agents can kill proliferating cells by damaging DNA or microtubules. Although numerous cancer cells are sensitive to chemotherapy despite their low proliferation, called «the proliferating rate paradox» by Mitchison TJ, quiescent cells are usually insensitive to cytotoxic agents [119] and can be reactivated in an adequate microenvironment [29, 84, 91]. In this context, the disruption of the dialogue between cancer cells and their microenvironment is a promising therapeutic approach in bone sarcomas. Migration, survival and proliferation are controlled by a complex internal cell machinery but also by several external factors such as cytokines or growth-activating tyrosine kinase receptors [120]. Several clinical trials are in progress to assess tyrosine kinase inhibitors which are considered as multi-target drugs (Tables 2, 3; Fig. 3). Regorafenib an oral multikinase inhibitor targeting angiogenic factors (VEGFR1-3, TIE2), oncogenic kinases (KIT, RET, RAF) and pazopanib inhibiting VEGFR, PDGFR and cKIT are going to be assessed in osteosarcoma (Fig. 3) [120, 121]. First therapeutic response has been described in three metastatic osteosarcoma [122] and Ewing sarcoma 


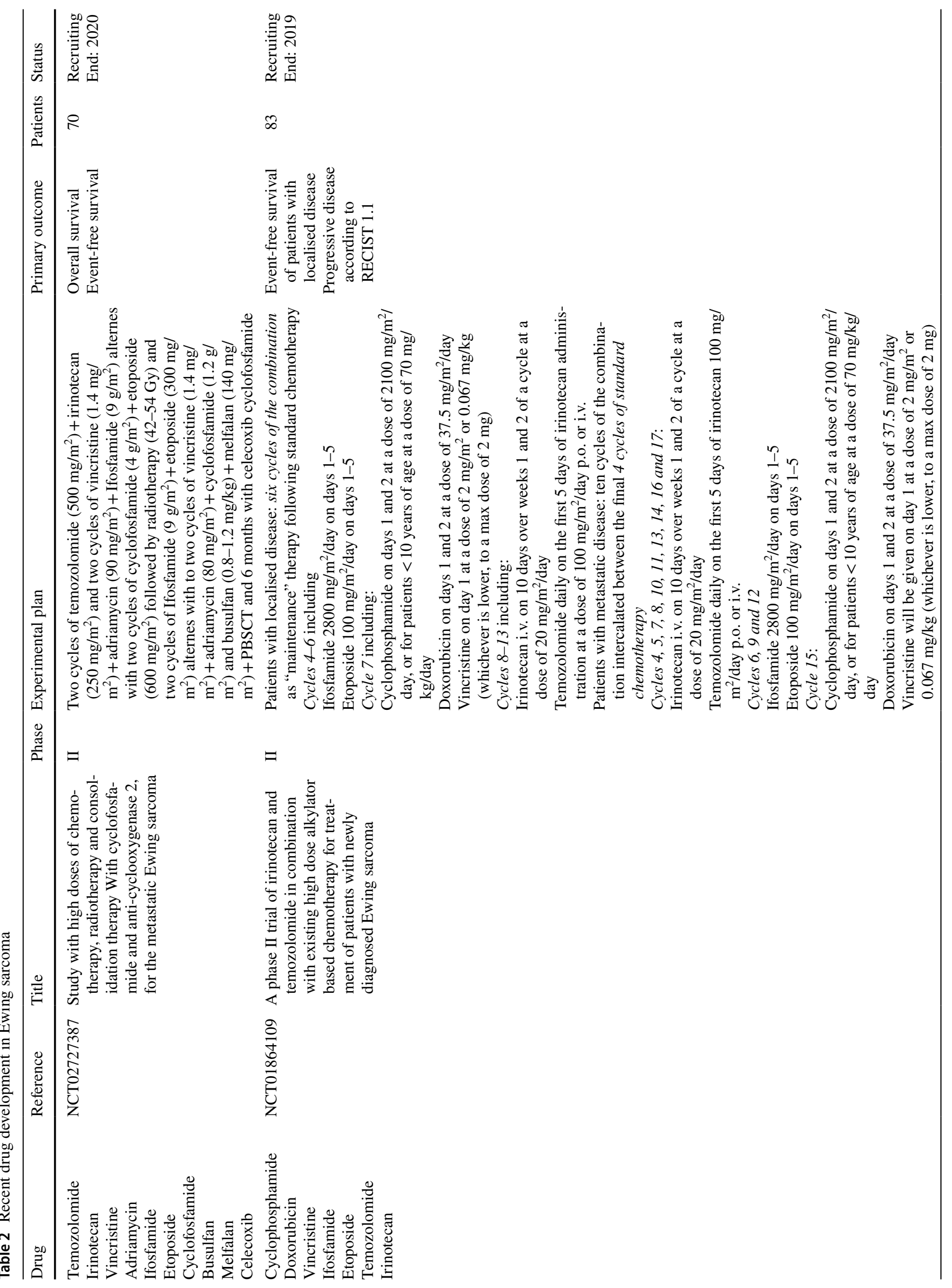




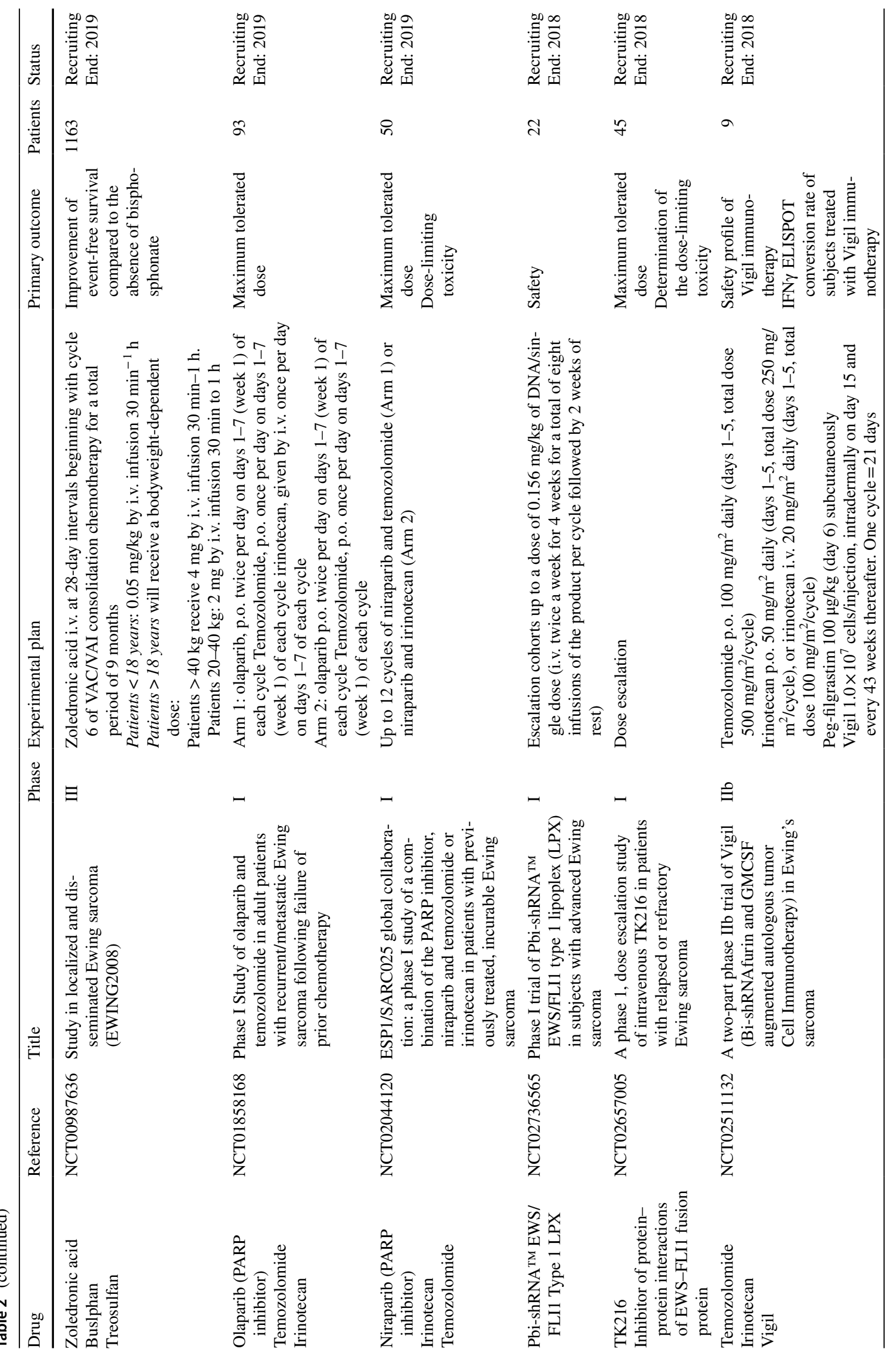




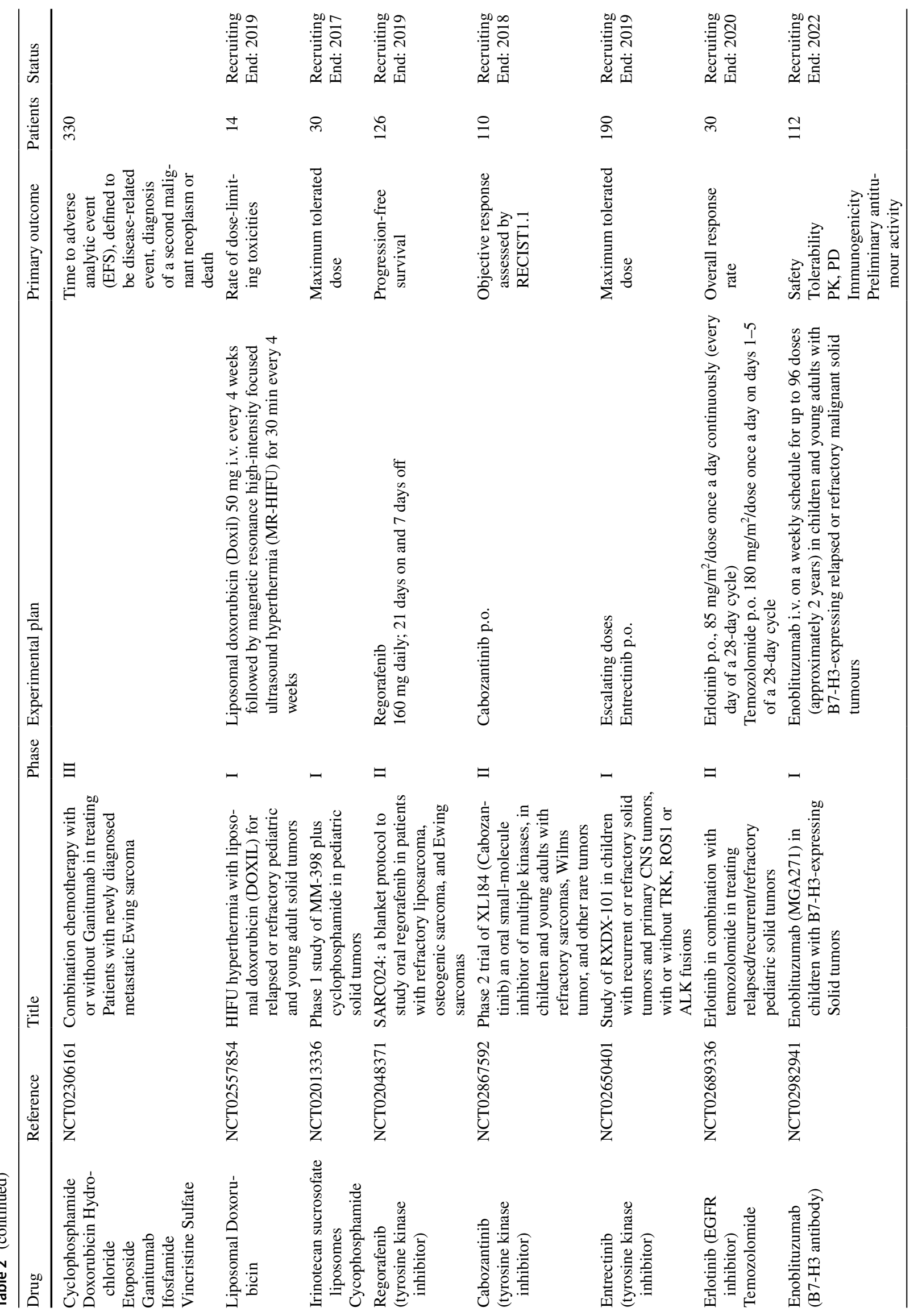




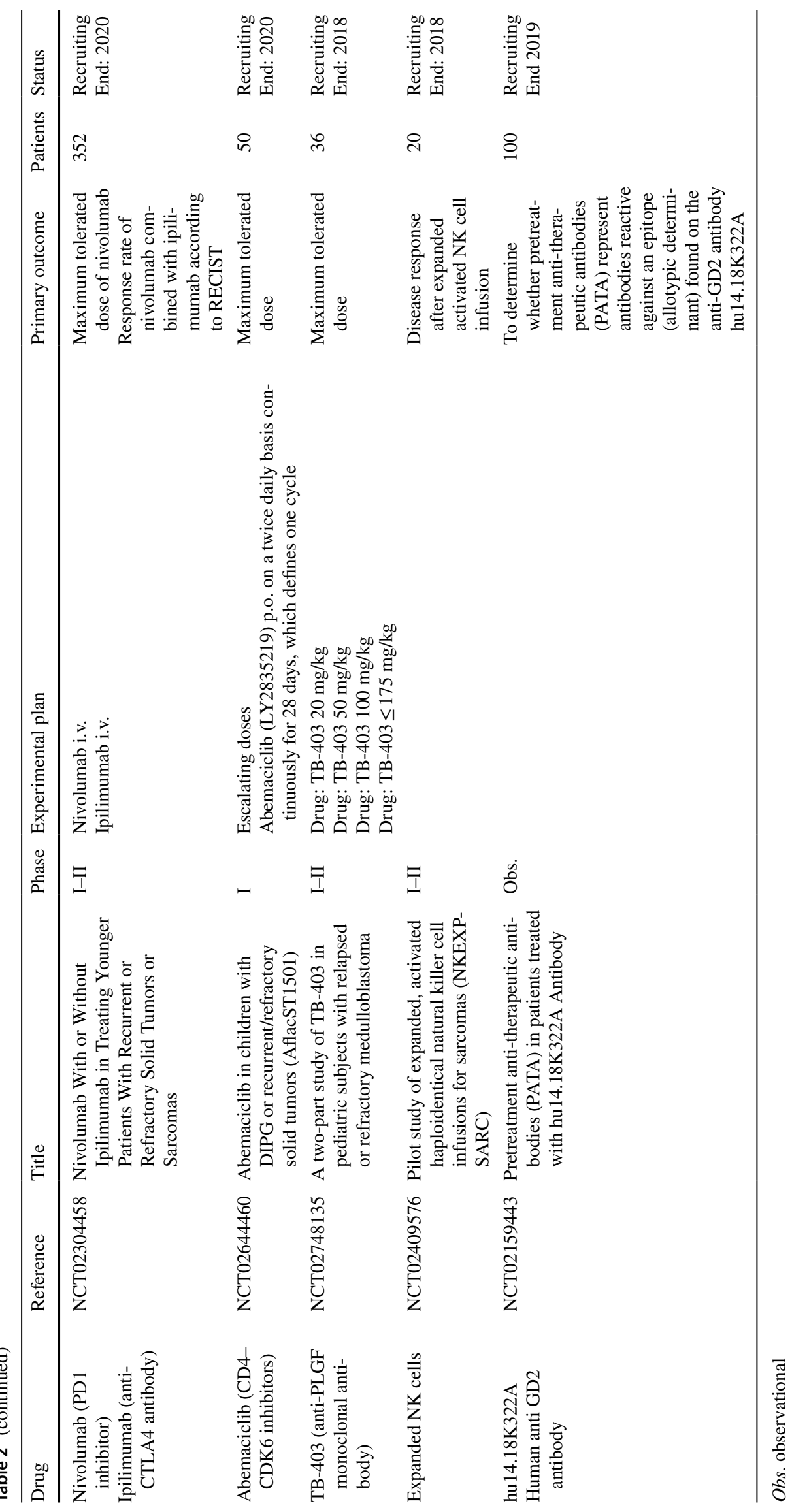




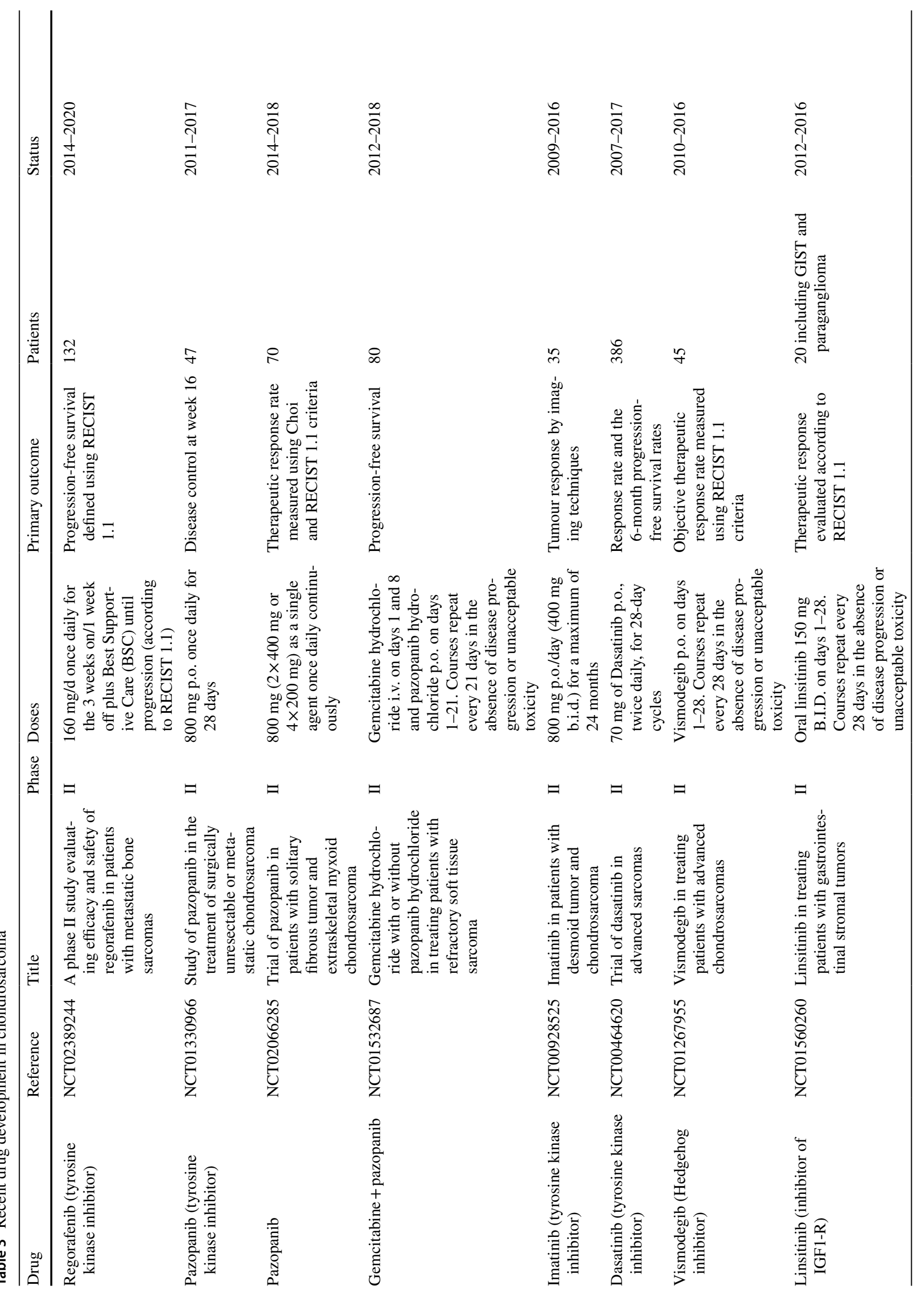




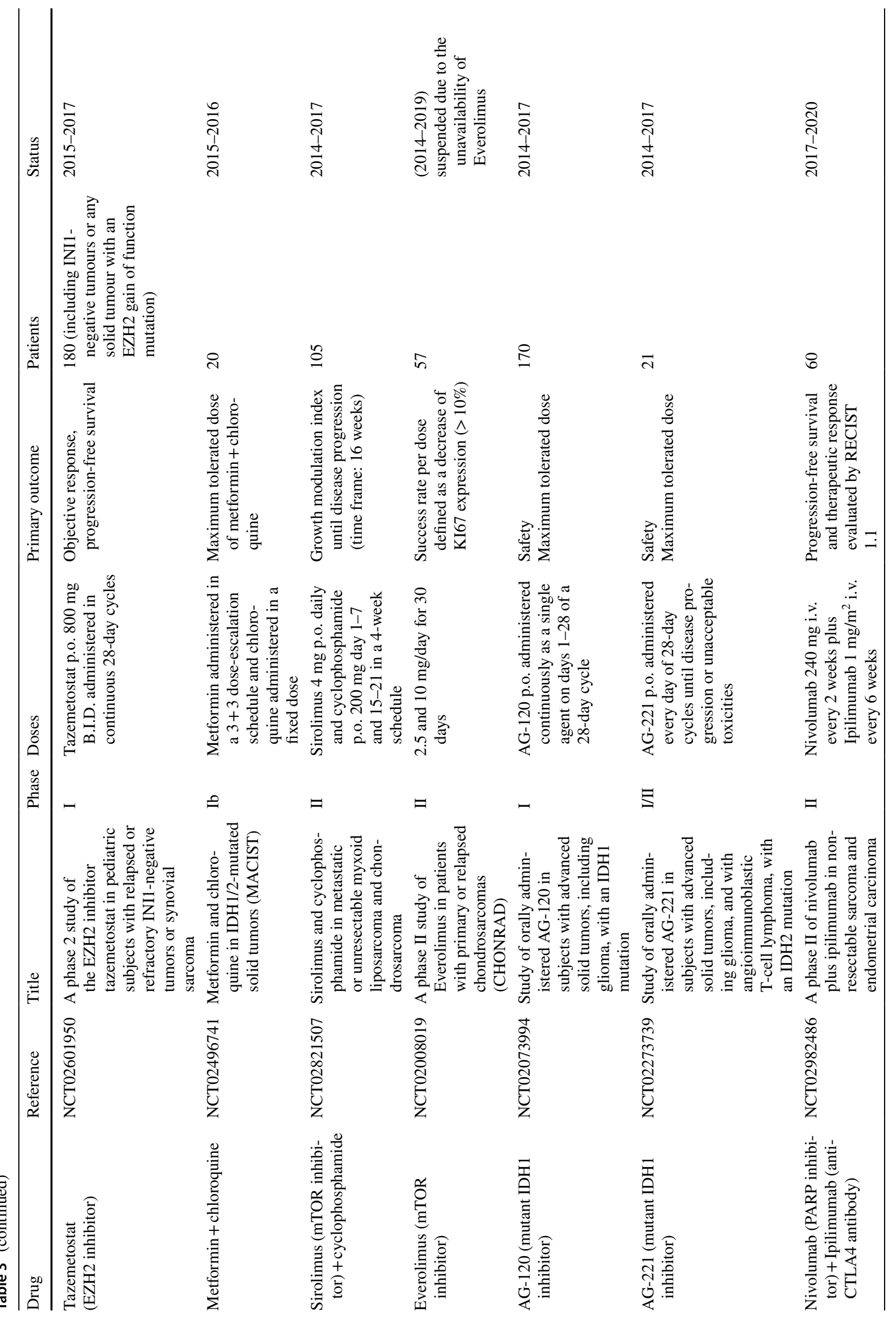


[123] patients treated with pazopanib. Similarly, regorafenib showed its antitumour activity in osteosarcoma in a phase I clinical trial [124], a phase II is in progress and will include 126 patients treated daily with oral $160 \mathrm{mg}$ regorafenib. Erlotinib targeting the EGFR, cabozantinib blocking cMET and entrectinib, a selective inhibitor of TrkA, B and C, C-ros oncogene 1 and ALK are also in phase II in rare tumours including Ewing sarcoma (Table 2).

\section{Bone Targeting}

Ewing sarcoma cells activate osteoclastogenesis followed by increased bone resorption and in this context the blockade of osteoclast activation by a bisphosphonate showed therapeutic benefit in a pre-clinical model of Ewing sarcoma [71]. A phase III clinical trial including more than 1150 patients treated with zoledronate is currently on-going with primary completion by March 2019. Radium-223 $\left.{ }^{223} \mathrm{Ra}\right)$ is an alphaemitting radiopharmaceutical compound which showed calcimimetic properties and consequently has intrinsic calcified tissue-targeting properties. Based on these specificities, the bone matrix is the preferential site of biodistribution. The first clinical evidence of response to radium-223 in osteosarcoma has been published by Subbiah et al. who described a reduction of bone pain and bone-remodelling parameters after treatment [125]. A phase I/II clinical trial is on-going (NCT01833520, «Phase I Dose Escalation of Monthly Intravenous Ra-223 Dichloride in Osteosarcoma») to determine the maximum tolerated dose of radium-223 dichloride for treating osteosarcoma patients. Fifteen patients have been enrolled and were treated with a starting dose of radium-223 dichloride $(50 \mathrm{kBq} / \mathrm{kg}$ i.v. over several minutes on day 1 of each 4-week cycle). The final completion will be at the end of 2018 [112].

\section{DNA Repair Targeting}

Poly(ADP-ribose) polymerase 1 (PARP1) is a key protein involved in DNA repair especially in DNA repair of single-strand breaks. In 2012, Garnett et al. have reported a high sensitivity of Ewing sarcoma cells to PARP inhibitors [126]. Based on this interesting observation, a first phase II trial was set up in Ewing sarcoma. Unfortunately, the results revealed the absence of efficacy of olaparib as a single agent [127]. However, pre-clinical studies demonstrated promising benefit when combining PARP inhibitors with other targeting pathways (e.g. IGF1 inhibition, Trabectedin, temozolomide) and justified several phase I clinical trials (NCT01858168, NCT02044120) [128]. In 2015, Kovac et al. studied 31 osteosarcoma samples by exosome sequencing and showed for the first time recurrent mutation signatures of BRCA deficiency [31]. This observation could be an excellent argument to assess the therapeutic efficacy 
Fig. 3 Recent on-going clinical trials in osteosarcoma. Numerous therapeutic approaches are in clinical development and are based on specific and direct targeting of cancer cells (e.g. DNA repair, cell cycle or glycoprotein targeting), or indirect targeting of cancer cells by modulation of their microenvironment (e.g. immunotherapies). After integration in extracellular tumour bone matrix, alpha radiotherapeutic agents can indirectly kill the cancer cells. NCT: National Clinical Trial NuClinicalTrials. gov registry Number

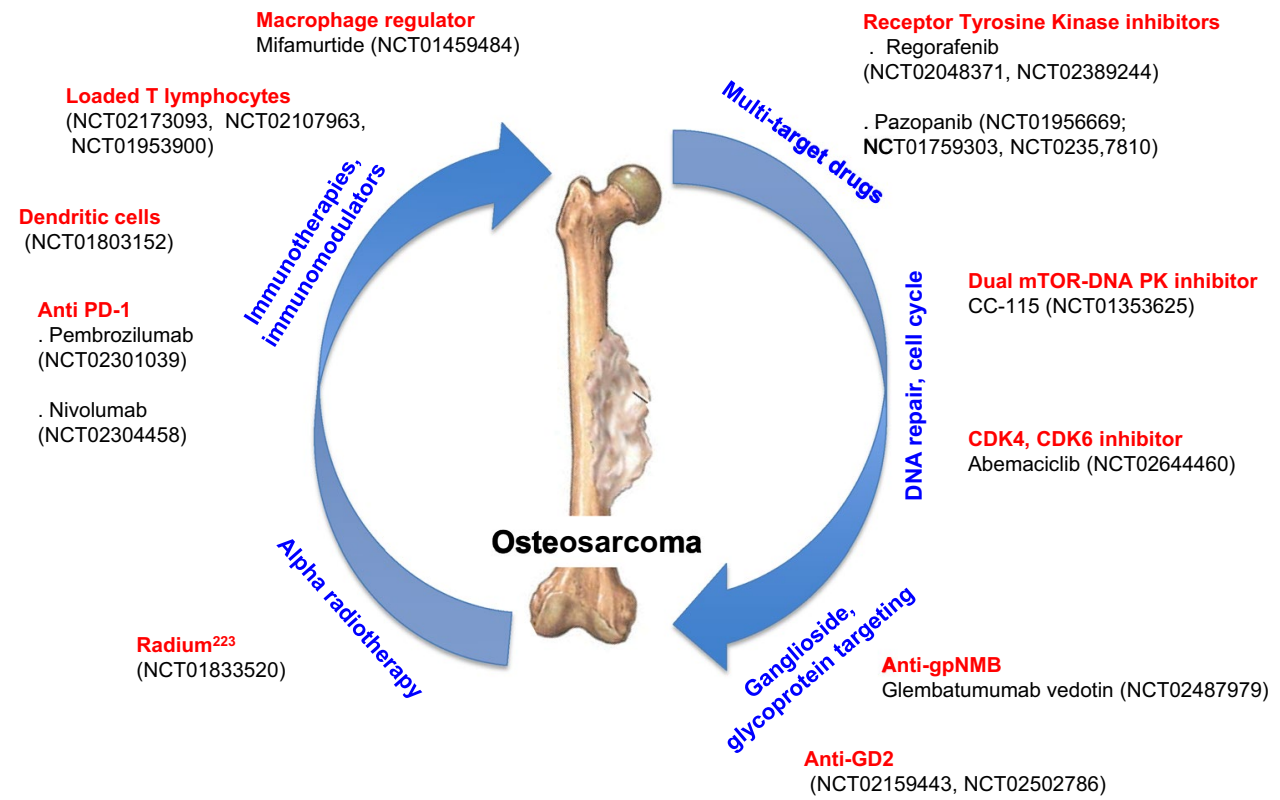

of PARP inhibitors in osteosarcoma and clinical trials are in discussion.

\section{Immunotherapies}

The immune system plays a key role in cancer and immune cells recruited by cancer cells (e.g. lymphocytes, dendritic cells, macrophages) are responsible for a local immune tolerance and T lymphocytes infiltrating osteosarcoma tissues [110]. Programmed cell death ligand 1 (PDL-1) is a cellsurface protein that represses the cytotoxic $\mathrm{CD} 8^{+} \mathrm{T}$-cellmediated immune response. PDL-1 is frequently highly expressed by cancer cells and has become a strategic target in oncology $[109,129,130]$. PD-1 and PDL-1 have also been reported to be expressed by some osteosarcoma, Ewing sarcoma and giant cell tumours of bone as well as in softtissue sarcoma [131]. Shen et al. analysed the expression of PDL-1 in osteosarcoma samples and revealed its expression in a subset of osteosarcoma as well as a correlation between PDL-1 expression and T lymphocyte infiltration [132]. More recently, Sandara et al. demonstrated an increased PDL-1 expression and T-cell infiltration in metastatic high-grade osteosarcoma strengthening the clinical interest of PDL-1/ PD-1 inhibition in osteosarcoma [133]. Paoluzzi et al. retrospectively analysed a cohort of 28 patients with relapsed metastatic/unresectable soft-tissue and bone sarcomas, who were treated with i.v. nivolumab (anti-PD1) $3 \mathrm{mg} / \mathrm{kg}$ every 2 weeks with or without pazopanib at $400-800 \mathrm{mg}$ daily [134]. They observed three partial responses, nine stable disease and twelve patients had progression of disease. The authors concluded that a clinical benefit was observed in $50 \%$ of the evaluable patients. Based on these observations, the assessment of two anti-PD1 antibodies, pembrolizumab
(NCT02301039) and nivolumab (NCT02304458) are in progress in osteosarcoma (Fig. 3). PD-1 inhibitor (nivolumab) is currently assessed in Ewing sarcoma in combination with an anti CTLA-4 antibody (Ipilimumab) (Table 2).

Preparation of immune cells such as dendritic cells, loaded T lymphocytes and NK (natural killer) cells are also in evaluation in phase I/II clinical trials in osteosarcoma (Fig. 3) and Ewing sarcoma (Table 2). The main goal of these studies is to lift the local immune tolerance and to reactivate the immune response against cancer cells. Thus, a pilot study (NCT02409576) in which activated haploidentical NK cells will be administered in 20 sarcoma patients is currently being carried out. The primary outcome will be clinical response (estimated primary completion date: end 2018).

Macrophage infiltration contributes to the control of osteosarcoma growth [105-107]. From this observation, several therapeutic strategies have been developed. One of the more "polemical" agents is Mifamurtide (L-MTP-PE), a synthetic analogue of a bacterial wall component able to activate macrophages resulting in improvement of overall survival by around $10 \%$ in combination with chemotherapy [113]. However, due to some controversy on the design of the study, its use is not universally admitted and a phase II/III clinical trial is on-going (NCT01459484). This trial will enrol more than 200 patients. Mifamurtide $\left[2 \mathrm{mg} / \mathrm{m}^{2}\right.$ twice a week for the first 3 months, then weekly for the next 6 months (total length of treatment 44 weeks)] will be added as post-surgery regimen in association with chemotherapy. Patients will be identified as good or bad responders according to the expression levels of P-glycoprotein. The estimated primary completion date is beginning of 2020 . 


\section{Fusion Protein Targeting}

Ewing sarcoma are characterised by a $\mathrm{t}(11 ; 22)$ (q24; q12) translocation resulting in the EWS/FLil fusion gene considered as a driver gene for the disease. New therapeutic approaches targeting EWS/FLil gene or the corresponding protein have been set up (Table 2).

Based on the pre-clinical data on EWS-Fli1 silencing $[13,14]$, a phase I clinical trial has been designed for the treatment of Ewing sarcoma patients by a shRNA EWS/Fli1 type lipoplex (NCT02736565, Table 2). A dose escalation study of intravenous shRNA EWS/Fli1 type lipoplex (up to $0.156 \mathrm{mg} / \mathrm{kg}$ of DNA/single dose) will be carried out. The drug will be administered twice a week for 4 weeks for a total of eight infusions per cycle followed by 2 weeks of rest. Adverse effect and the therapeutic response will be assessed (estimated study completion date: end 2019). Similarly, TK216 is a chemical compound developed to inhibit downstream effects of the EWS-FLi1 transcription factor (NCT02657005, Table 2). The maximum tolerated dose will be determined in a phase I clinical trial.

\section{Cyclin-Dependent Kinase Inhibitors}

CDK4 and CDK6 are kinases involved in the control of the cell cycle and act in G1 phase. In order to block cell proliferation, cyclin-dependent kinase inhibitors have been designed. Among them, Abemaciclib inhibits CD4 and CDK6 and induces a cell cycle arrest in G1 phase by acting on $\mathrm{Rb}$ phosphorylation. Fifty patients including osteosarcoma and Ewing sarcoma patients will be enrolled in a phase I clinical trial (NCT02644460) to determine the maximum tolerated dose (estimated study completion date: 2020).

\section{Disialoganglioside (GD2) Targeting and Drug Resistance (gpNMB)}

A recent study revealed that most osteosarcoma and Ewing sarcoma expressed GD2, which is suspected to enhance tumour aggressiveness [135]. A phase II clinical study is in progress [NCT02502786, «Humanized monoclonal antibody 3F8 (Hu3F8) with Granulocyte-Macrophage Colony-Stimulating Factor (GM-CSF) in the treatment of recurrent osteosarcoma»]. Patients are treated with three doses of hu3F8 $(2.4 \mathrm{mg} / \mathrm{kg} / \mathrm{dose}$ for 3 days) and 10 days of GM-CSF (five cycles maximum). The primary outcome is the event-free survival. Glycoprotein non-metastatic melanoma protein B (gpNMB) is highly expressed in solid tumours and promotes metastatic progression by modulation of invasion and migration. A phase II clinical trial (NCT01353625) is evaluating the therapeutic benefit of Glembatumumab vedotin, an antibody-drug conjugate targeting gpNMB, in osteosarcoma patients. Patients with recurrent disease or refractory to conventional therapy have been included. The primary outcome is the dose-limiting toxicity and non-tolerated dose (estimated primary completion date: end 2018).

\section{Novelties in Chondrosarcoma}

Chondrosarcoma comprises chemo- and radioresistant tumours with high risk of recurrence and surgery remains the treatment of choice. Due to their common origin, numerous new clinical approaches are similar to those proposed for osteosarcoma and Ewing sarcoma (Table 3). Because chondrosarcoma cells are sensitive to soluble factors produced by their microenvironment and activate various tyrosine kinase receptors, several tyrosine kinase inhibitors are clinically assessed alone or in combination: regorafenib, pazopanib, dasatinib (Bcr-Abl and Src family tyrosine kinase inhibitor), imatinib (Bcr-Abl, cKIT, RET, NGF-R, PDGFR $\alpha / \beta$, ABL1, M-CSFR). mTOR plays a role in the control of numerous basic biological functions such as proliferation and migration and acts as a nutriment sensor. One of the best inhibitors used in clinic is rapamycin (sirolimus) which can inhibit mTOR after its binding to FKBP12 and acts as an immunosuppressive agent. Bernstein-Molho et al. analysed the effect of mTOR inhibition by sirolimus combined with cyclophosphamide in a series of 49 recurrent unresectable chondrosarcomas [136]. The combination of both agents was well tolerated with no significant adverse effects and could have therapeutic benefit. Indeed, $10 \%$ of objective response and $60 \%$ of stabilisation of disease for at least 6 months were observed. A phase II clinical trial is on-going associating both agents in unresectable chondrosarcoma (NCT02821507, Table 3). Everolimus, targeting mTORC1 (mTOR complex 1), appeared efficacious as single agent in a rat chondrosarcoma model [137] and a phase II clinical trial has been designed to evaluate its therapeutic efficacy in primary or relapsed chondrosarcoma (NCT02008019, Table 3).

IDH-1 or -2 are frequently mutated in malignant cartilaginous tumours and two phase I clinical trials are in progress with AG-120, a mutant IDH-1 inhibitor (NCT02073994) and AG-221, a mutant IDH2 inhibitor (NCT02273739).

Chondrosarcoma development is associated with the infiltration of immune cells [65]. In an in vivo rat chondrosarcoma model, Simard et al. demonstrated a positive impact on tumour growth after selective $\mathrm{T}$ cell depletion in contrast to the depletion of $\mathrm{CD} 163^{+}$macrophages resulting in a slowdown of tumour development [65]. These results showed the clear implication of the immune system on the pathogenesis of chondrosarcoma and the clinical interest to assess new inhibitors of immune checkpoints. These observations were confirmed more recently by Kostine et al. who demonstrated that $41-52 \%$ of dedifferentiated chondrosarcomas displayed PD-L1 positivity [138]. A phase II clinical trial is on-going 
and patients will be treated by intravenous pembrolizumab at $200 \mathrm{mg}$ every 3 weeks (NCT02301039, Table 3 ).

\section{Giant Cell Tumours of Bone: Benign Tumours with Malignant-Like Properties}

In the field of bone sarcoma, giant cell tumours (GCTs) have a special status. Indeed, GCTs are benign tumours with no nuclear cytologic aberration, intensively damaging the host bone and the cells can spread to the soft tissue in a similar manner to a malignant tumour [139-141]. Indeed, highgrade malignant neoplasm can be identified at the time of diagnosis or subsequent surgery (secondary malignancy in GCT) or radiotherapy. Giant cell tumours of bone are rare tumours with an incidence of around 1 new case per 100,000 people per year and affect mainly young adults on the second and third decade. The ratio male/female of $1: 2$ is in favour of the female. The tumour tissue is characterised by three main cellular components: (i) giant multinucleated cells (osteoclast-like cells), (ii) mononuclear macrophages and (iii) mononuclear stromal cells (Fig. 4). Stromal cells secrete numerous pro-myeloid factors such as M-CSF and proosteoclastic factors such as RANKL resulting in monocyte/ macrophage proliferation and osteoclastogenesis. Indeed, osteoclast precursors have monocytic/macrophagic origin and can proliferate, fuse and differentiate in the presence of M-CSF and RANKL (Fig. 4). RANKL is mandatory for osteoclastogenesis. RANKL binds to three distinct receptors: (i) RANK: a transmembrane receptor expressed at the surface of osteoclasts and their precursors and is responsible for osteoclast differentiation; (ii) OPG: a soluble decoy receptor blocking the binding of RANKL to RANK and therefore considered as an anti-bone catabolic agent, (iii) LGR-4 expressed at the cell membrane of osteoclasts and which negatively regulates osteoclast differentiation (Fig. 4) [142]. The origin of giant cell tumours of bone has been controversial for a long time. Nowadays, it is widely accepted that the stromal component is "the tumoural" element of the tissue and its dysregulation leads to the recruitment, proliferation and differentiation of macrophages. The clinical consequence is massive local bone destruction (Fig. 4). The current treatment is based on a resection surgery but unfortunately frequent recurrences associated with a high morbidity are observed. This is followed by a possible malignant transformation with a metastatic profile after up to 20 years.

Similar to other bone sarcomas, the local microenvironment is crucial in the tumour development and the osteolytic process. In this context, anti-bone resorption agents have been assessed in clinical trials with great success [143, 144]. A phase II clinical trial (NCT01564121) has assessed zoledronic acid in 24 patients [144]. The patients were treated with extensive intralesional curettage
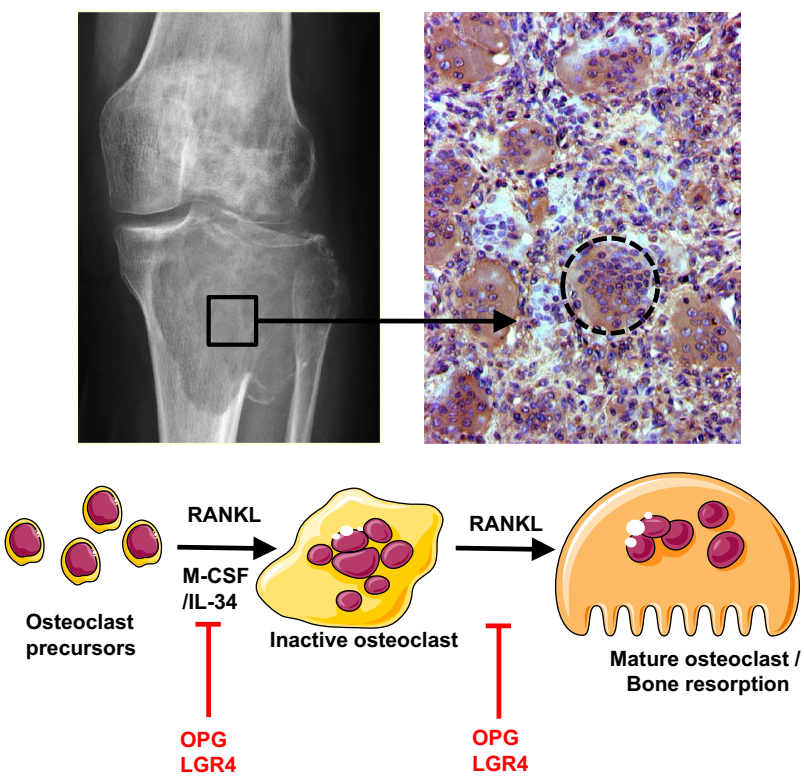

Fig. 4 Giant cell tumours of bone: a benign entity with malignant features. Giant cell tumours of bone are composed of three main cell populations: stromal cells, macrophages and multinucleated osteoclast-like cells. These tumours are responsible for a marked local bone resorption leading to the formation of large osteolytic foci easily detectable by X-ray radiography. RANKL/M-CSF and/or RANKL/ IL-34 released by stromal cell could induce the differentiation of macrophages considered as osteoclast precursors towards immature and mature osteoclasts resorbing bone. Soluble OPG and membrane LGR4 are two receptors that negatively control osteoclastogenesis. OPG acts as a decoy receptor to RANK resulting in blocked RANKL-RANK interactions. LGR4 is expressed by osteoclasts and binds to RANKL leading to G $\alpha \mathrm{q} / \mathrm{GS} 3 \mathrm{~K}-\beta$ signalling and repression of the NFATc1 molecular pathway. IL-34 Interleukin-34, LGR-4 G-protein-coupled receptor 4, $M$-CSF Macrophage Colony-Stimulating Factor, $O P G$ osteoprotegerin, RANKL Receptor of Nuclear factor kappaB Ligand

followed by five courses of bisphosphonate. Unfortunately, even if short adjuvant treatments with zoledronic acid were associated with a low rate of recurrence, the study did not show any significant impact on local recurrence. Denosumab, a humanised blocking antibody against RANKL, is currently evaluated in a series of 586 patients in a phase II clinical trial (NCTNCT00680992) [102]. Denosumab was administered subcutaneously at a dose of $120 \mathrm{mg}$ every 4 weeks and a loading dose of $120 \mathrm{mg}$ s.c. on study days 8 and 15 . The intermediate results showed the safety of the drug and first clinical benefit with at least $90 \%$ of tumour necrosis after denosumab administration (estimated completion date: end 2017). Preoperative pretreatment is currently in discussion to facilitate the surgical resection in patients with aggressive tumours with high-risk location (e.g. spine). 


\section{Conclusion}

Bone sarcomas are rare and heterogeneous diseases. Most bone sarcomas originate from MSCs and share a common feature with a marked implication of the local environment in their pathogenesis. This microenvironment appears as an impressive source of therapeutic targets and is leading to the design of numerous promising clinical trials. However, the tumour microenvironment of bone sarcomas is also very heterogeneous and includes numerous cell types, all of them composed by heterogeneous sub-clones. A better characterisation is the key challenge for a better patient stratification and development of personalised medicine.

Funding The funding was provided by Bone Cancer Research Trust (144681)

Open Access This article is distributed under the terms of the Creative Commons Attribution 4.0 International License (http://creativecommons.org/licenses/by/4.0/), which permits unrestricted use, distribution, and reproduction in any medium, provided you give appropriate credit to the original author(s) and the source, provide a link to the Creative Commons license, and indicate if changes were made.

\section{References}

1. Stiller CA, Craft AW, Corazziari I (2001) Survival of children with bone sarcoma in Europe since 1978: results from the EUROCARE study. Eur J Cancer 37:760-766. https://doi.org/10.1016/ S0959-8049(01)00004-1

2. The ESMO/European Sarcoma Network Working Group (2012) Bone sarcomas: ESMO Clinical Practice Guidelines for diagnosis, treatment and follow-up. Ann Oncol 23:vii100-vii109. https://doi.org/10.1093/annonc/mds254

3. Heymann D (2014) Bone cancer: primary bone cancer an bone metastases, 2nd edn. Elsevier, San Diego

4. Heymann D, Redini F (2011) Bone sarcomas: pathogenesis and new therapeutic approaches. IBMS BoneKEy 8:402-414. https:// doi.org/10.1138/20110531

5. Deschaseaux F, Sensébé L, Heymann D (2009) Mechanisms of bone repair and regeneration. Trends Mol Med 15:417-429. https://doi.org/10.1016/j.molmed.2009.07.002

6. Panaroni C, Tzeng YS, Saeed H, Wu JY (2014) Mesenchymal progenitors and the osteoblast lineage in bone marrow hematopoietic niches. Curr Osteoporos Rep 12:22-32. https://doi. org/10.1007/s11914-014-0190-7

7. Garg P, Mazur MM, Buck AC, Wandtke ME, Liu J, Ebraheim NA (2017) Prospective review of mesenchymal stem cells differentiation into osteoblasts. Orthop Surg 9:13-19. https://doi. org/10.1111/os.12304

8. Mohseny AB, Hogendoorn PC (2011) Concise review: mesenchymal tumors: when stem cells go mad. Stem Cells 29:397-403. https://doi.org/10.1002/stem.596

9. Wagner ER, Luther G, Zhu G, Luo Q, Shi Q, Kim SH, Gao JL, Huang E, Gao Y, Yang K, Wang L, Teven C, Luo X, Liu X, Li M, Hu N, Su Y, Bi Y, He BC, Tang N, Luo J, Chen L, Zuo G, Rames R, Haydon RC, Luu HH, He TC (2011) Defective osteogenic differentiation in the development of osteosarcoma. Sarcoma 2011:325238. https://doi.org/10.1155/2011/325238
10. Mohseny AB, Szuhai K, Romeo S, Buddingh EP, Briaire-de Bruijn I, de Jong D, van Pel M, Cleton-Jansen AM, Hogendoorn PC (2009) Osteosarcoma originates from mesenchymal stem cells in consequence of aneuploidization and genomic loss of Cdkn2. J Pathol 219:294-305. https://doi.org/10.1002/path.2603

11. Tang X, Lu X, Guo W, Ren T, Zhao H, Zhao F, Tang G (2010) Different expression of Sox9 and Runx2 between chondrosarcoma and dedifferentiated chondrosarcoma cell line. Eur J Cancer Prev 19:466-471. https://doi.org/10.1097/ CEJ.0b013e32833d $942 f$

12. de Andrea CE, Reijnders CM, Kroon HM, de Jong D, Hogendoorn PC, Szuhai K, Bovée JV (2012) Secondary peripheral chondrosarcoma evolving from osteochondroma as a result of outgrowth of cells with functional EXT. Oncogene 31:10951104. https://doi.org/10.1038/onc.2011.311

13. Zuntini M, Pedrini E, Parra A, Sgariglia F, Gentile FV, Pandolfi M, Alberghini M, Sangiorgi L (2010) Genetic models of osteochondroma onset and neoplastic progression: evidence for mechanisms alternative to EXT genes inactivation. Oncogene 29:3827-3834. https://doi.org/10.1038/onc.2010.135

14. Musso N, Caronia FP, Castorina S, Lo Monte AI, Barresi V, Condorelli DF (2015) Somatic loss of an EXT2 gene mutation during malignant progression in a patient with hereditary multiple osteochondromas. Cancer Genet 208:62-67. https://doi. org/10.1016/j.cancergen.2015.01.002

15. The Delattre O, Zucman J, Melot T, Garau XS, Zucker JM, Lenoir GM, Ambros PF, Sheer D, Turc-Carel C, Triche TJ, Aurias A, Thomas G. Ewing family of tumors-a subgroup of small-round-cell tumors defined by specific chimeric transcripts. N Engl J Med 331:294-299. https://doi.org/10.1056/ NEJM199408043310503

16. Tirode F, Laud-Duval K, Prieur A, Delorme B, Charbord P, Delattre O (2007) Mesenchymal stem cell features of Ewing tumors. Cancer Cell 11:421-429. https://doi.org/10.1016/j. ccr.2007.02.027

17. von Levetzow C, Jiang X, Gwye Y, von Levetzow G, Hung L, Cooper A, Hsu JH, Lawlor ER (2011) Modeling initiation of Ewing sarcoma in human neural crest cells. PLoS ONE 6:e19305. https://doi.org/10.1371/journal.pone.0019305

18. Tanaka M, Yamazaki Y, Kanno Y, Igarashi K, Aisaki K, Kanno J, Nakamura T (2014) Ewing's sarcoma precursors are highly enriched in embryonic osteochondrogenic progenitors. J Clin Investig 124:3061-3074. https://doi.org/10.1172/JCI72399

19. Riggi N, Cironi L, Provero P, Suva ML, Kaloulis K, GarciaEcheverria C, Hoffmann F, Trumpp A, Stamenkovic I (2005) Development of Ewing's sarcoma from primary bone marrowderived mesenchymal progenitor cells. Cancer Res 65:1145911468. https://doi.org/10.1158/0008-5472.CAN-05-1696

20. Uluçkan Ö, Segaliny A, Botter S, Santiago JM, Mutsaers AJ (2015) Preclinical mouse models of osteosarcoma. BoneKEy Rep 4:670. https://doi.org/10.1038/bonekey.2015.37

21. Botter SM, Arlt MJE, Fuchs B (2015) Mammalian models of bone sarcomas. In: Heymann D (ed) Bone cancer, second edition, chapter 30. Elsevier, San Diego, pp 349-364. https://doi. org/10.1016/B978-0-12-416721-6.00030-3

22. Cleton-Jansen AM, (2015) Zebrafish models for studying bone cancers: mutants, transgenic fish and embryos. In: Heymann D (ed) Bone cancer, second edition, chapter 31. Elsevier, San Diego, pp 365-370. https://doi.org/10.1016/ B978-0-12-416721-6.00031-5

23. Walkley CR (2015) Modeling osteosarcoma: in vitro and in vivo approaches. In: Heymann D (ed) Bone cancer, second edition, chapter 17. Elsevier, San Diego, pp 195-204. https://doi. org/10.1016/B978-0-12-416721-6.00017-0 
24. Hoffman RM (2015) Patient-derived orthotopic xenografts: better mimic of metastasis than subcutaneous xenografts. Nat Rev Cancer 15:451-452. https://doi.org/10.1038/nrc3972

25. Sampson VB, Kamara DF, Kolb EA (2013) Xenograft and genetically engineered mouse model systems of osteosarcoma and Ewing's sarcoma: tumor models for cancer drug discovery. Expert Opin Drug Discov 8:1181-1189. https://doi.org/10.1517 /17460441.2013.817988

26. Swarm RL, Correa JN, Andrews JR, Miller E (1964) Morphologic demonstration of recurrent tumor following $\mathrm{X}$ irradiation. Histologic study of irradiated murine chondrosarcoma transplants. J Natl Cancer Inst 33:657-672

27. van Oosterwijk JG, Plass JR, Meijer D, Que I, Karperien M, Bovée JV (2015) An orthotopic mouse model for chondrosarcoma of bone provides an in vivo tool for drug testing. Virchows Arch 466:101-109. https://doi.org/10.1007/s00428-014-1670-y

28. Monderer D, Luseau A, Bellec A, David E, Ponsolle S, Saiagh S, Bercegeay S, Piloquet P, Denis MG, Lodé L, Rédini F, Biger M, Heymann D, Heymann MF, Le Bot R, Gouin F, Blanchard F (2013) New chondrosarcoma cell lines and mouse models to study the link between chondrogenesis and chemoresistance. Lab Invest 93:1100-1114. https://doi.org/10.1038/labinvest.2013.101

29. Brown HK, Tellez-Gabriel M, Heymann D (2017) Cancer stem cells in osteosarcoma. Cancer Lett 386:189-195. https://doi. org/10.1016/j.canlet.2016.11.019

30. Bousquet M, Noirot C, Accadbled F, Sales de Gauzy J, Castex MP, Brousset P, Gomez-Brouchet A (2016) Whole-exome sequencing in osteosarcoma reveals important heterogeneity of genetic alterations. Ann Oncol 27:738-744. https://doi. org/10.1093/annonc/mdw009

31. Kovac M, Blattmann C, Ribi S, Smida J, Mueller NS, Engert F, Castro-Giner F, Weischenfeldt J, Kovacova M, Krieg A, Andreou D, Tunn PU, Dürr HR, Rechl H, Schaser KD, Melcher I, Burdach S, Kulozik A, Specht K, Heinimann K, Fulda S, Bielack S, Jundt G, Tomlinson I, Korbel JO, Nathrath M, Baumhoer D (2015) Exome sequencing of osteosarcoma reveals mutation signatures reminiscent of BRCA deficiency. Nat Commun 6:8940. https:// doi.org/10.1038/ncomms 9940

32. Kresse SH, Rydbeck H, Skårn M, Namløs HM, Barragan-Polania AH, Cleton-Jansen AM, Serra M, Liestøl K, Hogendoorn PC, Hovig E, Myklebost O, Meza-Zepeda LA (2012) Integrative analysis reveals relationships of genetic and epigenetic alterations in osteosarcoma. PLoS ONE 7:e48262. https://doi. org/10.1371/journal.pone.0048262

33. Balamuth NJ, Womer RB (2010) Ewing's sarcoma. Lancet Oncol 11:184-192. https://doi.org/10.1016/S1470-2045(09)70286-4

34. Burdach S, Jurgens H (2002) High-dose chemoradiotherapy (HDC) in the Ewing family of tumors (EFT). Crit Rev Oncol Hematol 41:169-189. https://doi.org/10.1016/ S1040-8428(01)00154-8

35. Iwamoto Y (2007) Diagnosis and treatment of Ewing's sarcoma. Jpn J Clin Oncol 37:79-89. https://doi.org/10.1093/jjco/hyl142

36. Llombart-Bosch A, Machado I, Navarro S, Bertoni F, Bacchini P, Alberghini M, Karzeladze A, Savelov N, Petrov S, AlvaradoCabrero I, Mihaila D, Terrier P, Lopez-Guerrero JA, Picci P (2009) Histological heterogeneity of Ewing's sarcoma/PNET: an immunohistochemical analysis of 415 genetically confirmed cases with clinical support. Virchows Arch 455:397-411. https:// doi.org/10.1007/s00428-009-0842-7

37. Zhang N, Liu H, Yue G, Zhang Y, You J, Wang H (2016) Molecular heterogeneity of Ewing sarcoma as detected by ion torrent sequencing. PLoS ONE 11(4):e0153546. https://doi.org/10.1371/ journal.pone.0153546

38. Bühnemann C, Li S, Yu H, Branford White H, Schäfer KL, Llombart-Bosch A, Machado I, Picci P, Hogendoorn PC, Athanasou NA, Noble JA, Hassan AB (2014) Quantification of the heterogeneity of prognostic cellular biomarkers in Ewing sarcoma using automated image and random survival forest analysis. PLoS ONE 9:e107105. https://doi.org/10.1371/journal. pone. 0107105

39. Sheffield NC, Pierron G, Klughammer J, Datlinger P, Schönegger A, Schuster M, Hadler J, Surdez D, Guillemot D, Lapouble E, Freneaux P, Champigneulle J, Bouvier R, Walder D, Ambros IM, Hutter C, Sorz E, Amaral AT, de Álava E, Schallmoser K, Strunk D, Rinner B, Liegl-Atzwanger B, Huppertz B, Leithner A, de Pinieux G, Terrier P, Laurence V, Michon J, Ladenstein R, Holter W, Windhager R, Dirksen U, Ambros PF, Delattre O, Kovar H, Bock C, Tomazou EM (2017) DNA methylation heterogeneity defines a disease spectrum in Ewing sarcoma. Nat Med 23:386-395. https://doi.org/10.1038/nm.4273

40. Franzetti GA, Laud-Duval K, van der Ent W, Brisac A, Irondelle M, Aubert S, Dirksen U, Bouvier C, de Pinieux G, Snaar-Jagalska E, Chavrier P, Delattre O (2017) Cell-to-cell heterogeneity of EWSR1-FLI1 activity determines proliferation/migration choices in Ewing sarcoma cells. Oncogene 36:3505-3514. https://doi. org/10.1038/onc.2016.498

41. Brohl AS, Solomon DA, Chang W, Wang J, Song Y, Sindiri S, Patidar R, Hurd L, Chen L, Shern JF, Liao H, Wen X, Gerard J, Kim JS, Lopez Guerrero JA, Machado I, Wai DH, Picci P, Triche T, Horvai AE, Miettinen M, Wei JS, Catchpool D, LlombartBosch A, Waldman T, Khan J (2014) The genomic landscape of the Ewing sarcoma family of tumors reveals recurrent STAG2 mutation. PLoS Genet 10:e1004475. https://doi.org/10.1371/ journal.pgen. 1004475

42. Huang HY, Illei PB, Zhao Z, Mazumdar M, Huvos AG, Healey JH, Wexler LH, Gorlick R, Meyers P, Ladanyi M (2005) Ewing sarcomas with p53 mutation or p16/p14ARF homozygous deletion: a highly lethal subset associated with poor chemoresponse. J Clin Oncol 23:548-558. https://doi.org/10.1200/ JCO.2005.02.081

43. Bovée JV, Cleton-Jansen AM, Taminiau AH, Hogendoorn PC (2005) Emerging pathways in the development of chondrosarcoma of bone and implications for targeted treatment. Lancet Oncol 6:599-607. https://doi.org/10.1016/ S1470-2045(05)70282-5

44. Bovée JV, Hogendoorn PC, Wunder JS, Alman BA (2010) Cartilage tumours and bone development: molecular pathology and possible therapeutic targets. Nat Rev Cancer 10:481-488. https:// doi.org/10.1038/nrc2869

45. Bovée JV, Hogendoorn PC, Wunder JS, Alman BA (2010) Cartilage tumours and bone development: molecular pathology and possible therapeutic targets. Nat Rev Cancer 10:481-488. https:// doi.org/10.1038/nrc2869

46. Fletcher CDM, Bridge JA, Hogendoorn P, Mertens F (2013) Who classification of tumours of soft tissue and bone, fourth edition, IARC Ed. ISBN-13 9789283224341\$4

47. Speetjens FM, de Jong Y, Gelderblom H, Bovée JV (2016) Molecular oncogenesis of chondrosarcoma: impact for targeted treatment. Curr Opin Oncol 28:314-322. https://doi.org/10.1097/ CCO.0000000000000300

48. O'Neal LW, Ackerman LV (1952) Chondrosarcoma of bone. Cancer 5:551-577. https://doi.org/10.1002/10970142(195205)5:3<551::AID-CNCR2820050317>3.0.CO;2-Z

49. Meijer D, de Jong D, Pansuriya TC, van den Akker BE, Picci P, Szuhai K, Bovée JV (2012) Genetic characterization of mesenchymal, clear cell, and dedifferentiated chondrosarcoma. Genes Chromosoms Cancer 51(10):899-909. https://doi.org/10.1002/ gcc. 21974

50. Amary MF, Bacsi K, Maggiani F, Damato S, Halai D, Berisha F, Pollock R, O'Donnell P, Grigoriadis A, Diss T, Eskandarpour M, Presneau N, Hogendoorn PC, Futreal A, Tirabosco R, Flanagan AM (2011) IDH1 and IDH2 mutations are frequent events in 
central chondrosarcoma and central and periosteal chondromas but not in other mesenchymal tumours. J Pathol 224:334-343. https://doi.org/10.1002/path.2913

51. Tarpey PS, Behjati S, Cooke SL, Van Loo P, Wedge DC, Pillay N, Marshall J, O'Meara S, Davies H, Nik-Zainal S, Beare D, Butler A, Gamble J, Hardy C, Hinton J, Jia MM, Jayakumar A, Jones D, Latimer C, Maddison M, Martin S, McLaren S, Menzies A, Mudie L, Raine K, Teague JW, Tubio JM, Halai D, Tirabosco R, Amary F, Campbell PJ, Stratton MR, Flanagan AM, Futreal PA (2013) Frequent mutation of the major cartilage collagen gene COL2A1 in chondrosarcoma. Nat Genet 45:923-926. https://doi. org/10.1038/ng.2668

52. Ottaviani G, Jaffe N (2009) The etiology of osteosarcoma. Cancer Treat Res 152:15-32. https://doi. org/10.1007/978-1-4419-0284-9_2

53. Fiorenza F, Abudu A, Grimer RJ, Carter SR, Tillman RM, Ayoub K, Mangham DC, Davies AM (2002) Risk factors for survival and local control in chondrosarcoma of bone. J Bone Joint Surg Br 84:93-99. https://doi. org/10.1302/0301-620X.84B1.11942

54. Wang ZQ, Ovitt C, Grigoriadis AE, Möhle-Steinlein U, Rüther U, Wagner EF (1992) Bone and haematopoietic defects in mice lacking c-fos. Nature 360(6406):741-745. https://doi. org/10.1038/360741a0

55. Wang ZQ, Liang J, Schellander K, Wagner EF, Grigoriadis AE (1995) c-fos-induced osteosarcoma formation in transgenic mice: cooperativity with c-jun and the role of endogenous c-fos. Cancer Res 55:6244-62451

56. Correa H (2016) Li-Fraumeni syndrome. J Pediatr Genet 5:8488. https://doi.org/10.1055/s-0036-1579759

57. Simon T, Kohlhase J, Wilhelm C, Kochanek M, De Carolis B, Berthold F (2010) Multiple malignant diseases in a patient with Rothmund-Thomson syndrome with RECQL4 mutations: case report and literature review. Am J Med Genet A 152A:15751579. https://doi.org/10.1002/ajmg.a.33427

58. Murata K, Hatamochi A, Shinkai H, Ishikawa Y, Kawaguchi N, Goto M (1999) A case of Werner's syndrome associated with osteosarcoma. J Dermatol 26:682-686. https://doi. org/10.1111/j.1346-8138.1999.tb02072.x

59. Lu L, Jin W, Liu H, Wang LL (2014) RECQ helicases and osteosarcoma. Adv Exp Med Biol 804:129-145. https://doi. org/10.1007/978-3-319-04843-7_7

60. Ng AJ, Walia MK, Smeets MF, Mutsaers AJ, Sims NA, Purton LE, Walsh NC, Martin TJ, Walkley CR (2015) The DNA helicase recql4 is required for normal osteoblast expansion and osteosarcoma formation. PLoS Genet 11(4):e1005160. https:// doi.org/10.1371/journal.pgen.1005160

61. Ren W, Gu G (2017) Prognostic implications of RB1 tumour suppressor gene alterations in the clinical outcome of human osteosarcoma: a meta-analysis. Eur J Cancer Care 26. https:// doi.org/10.1111/ecc.12401

62. Beltrami G, Ristori G, Scoccianti G, Tamburini A, Capanna R (2016) Hereditary Multiple Exostoses: a review of clinical appearance and metabolic pattern. Clin Cases Miner Bone Metab 13(2):110-118. https://doi.org/10.11138/ccmbm/2016.13.2.110

63. Czajka CM, DiCaprio MR (2015) What is the proportion of patients with multiple hereditary exostoses who undergo malignant degeneration? Clin Orthop Relat Res 473:2355-2361. https://doi.org/10.1007/s11999-015-4134-z

64. Alfranca A, Martinez-Cruzado L, Tornin J, Abarrategi A, Amaral T, de Alava E, Menendez P, Garcia-Castro J, Rodriguez R (2015) Bone microenvironment signals in osteosarcoma development. Cell Mol Life Sci 72:3097-3113. https://doi.org/10.1007/ s00018-015-1918-y

65. Simard FA, Richert I, Vandermoeten A, Decouvelaere AV, Michot JP, Caux C, Blay JY, Dutour A (2016) Description of the immune microenvironment of chondrosarcoma and contribution to progression. Oncoimmunology 6:e1265716. https://doi.org/1 $0.1080 / 2162402 X .2016 .1265716$

66. David E, Blanchard F, Heymann MF, De Pinieux G, Gouin F, Rédini F, Heymann D (2011) The bone niche of chondrosarcoma: a sanctuary for drug resistance, tumour growth and also a source of new therapeutic targets. Sarcoma 2011:932451. https://doi. org/10.1155/2011/932451

67. Bailey KM, Airik M, Krook MA, Pedersen EA, Lawlor ER (2016) Micro-Environmental stress induces Src-dependent activation of invadopodia and cell migration in Ewing sarcoma. Neoplasia 18:480-488. https://doi.org/10.1016/j.neo.2016.06.008

68. Lissat A, Joerschke M, Shinde DA, Braunschweig T, Meier A, Makowska A, Bortnick R, Henneke P, Herget G, Gorr TA, Kontny U (2015) IL6 secreted by Ewing sarcoma tumor microenvironment confers anti-apoptotic and cell-disseminating paracrine responses in Ewing sarcoma cells. BMC Cancer 15:552. https://doi.org/10.1186/s12885-015-1564-7

69. Paget $\mathrm{S}$. The distribution of secondary growths in cancer of the breast. Lancet 133:571-573. https://doi.org/10.1016/ S0140-6736(00)49915-0

70. Wittrant Y, Théoleyre S, Chipoy C, Padrines M, Blanchard F, Heymann D, Rédini F (2004) RANKL/RANK/OPG: new therapeutic targets in bone tumours and associated osteolysis. Biochim Biophys Acta 1704:49-57. https://doi.org/10.1016/j. bbcan.2004.05.002

71. Odri GA, Dumoucel S, Picarda G, Battaglia S, Lamoureux F, Corradini N, Rousseau J, Tirode F, Laud K, Delattre O, Gouin F, Heymann D, Redini F (2010) Zoledronic acid as a new adjuvant therapeutic strategy for Ewing's sarcoma patients. Cancer Res 70:7610-7619. https://doi.org/10.1158/0008-5472.CAN-09-4272

72. Moriceau G, Ory B, Mitrofan L, Riganti C, Blanchard F, Brion R, Charrier C, Battaglia S, Pilet P, Denis MG, Shultz LD, Mönkkönen J, Rédini F, Heymann D (2010) Zoledronic acid potentiates mTOR inhibition and abolishes the resistance of osteosarcoma cells to RAD001 (Everolimus): pivotal role of the prenylation process. Cancer Res 70:10329-10339. https://doi. org/10.1158/0008-5472.CAN-10-0578

73. Moriceau G, Ory B, Gobin B, Verrecchia F, Gouin F, Blanchard F, Redini F, Heymann D (2010) Therapeutic approach of primary bone tumours by bisphosphonates. Curr Pharm Des 16:29812987. https://doi.org/10.2174/138161210793563554

74. Ohba T, Cole HA, Cates JM, Slosky DA, Haro H, Ando T, Schwartz HS, Schoenecker JG (2014) Bisphosphonates inhibit osteosarcoma-mediated osteolysis via attenuation of tumor expression of MCP-1 and RANKL. J Bone Miner Res 29:14311445. https://doi.org/10.1002/jbmr.2182

75. Lamoureux F, Richard P, Wittrant Y, Battaglia S, Pilet P, Trichet V, Blanchard F, Gouin F, Pitard B, Heymann D, Redini F (2007) Therapeutic relevance of osteoprotegerin gene therapy in osteosarcoma: blockade of the vicious cycle between tumor cell proliferation and bone resorption. Cancer Res 67:7308-7318. https://doi.org/10.1158/0008-5472.CAN-06-4130

76. Gouin F, Ory B, Rédini F, Heymann D (2006) Zoledronic acid slows down rat primary chondrosarcoma development, recurrent tumor progression after intralesional curretage and increases overall survival. Int J Cancer 119:980-984. https:// doi.org/10.1002/ijc.21951

77. Ory B, Blanchard F, Battaglia S, Gouin F, Rédini F, Heymann D (2007) Zoledronic acid activates the DNA S-phase checkpoint and induces osteosarcoma cell death characterized by apoptosisinducing factor and endonuclease-G translocation independently of p53 and retinoblastoma status. Mol Pharmacol 71:333-343. https://doi.org/10.1124/mol.106.028837

78. Endo-Munoz L, Cumming A, Rickwood D, Wilson D, Cueva C, Ng C, Strutton G, Cassady AI, Evdokiou A, Sommerville 
S, Dickinson I, Guminski A, Saunders NA (2010) Loss of osteoclasts contributes to development of osteosarcoma pulmonary metastases. Cancer Res 70:7063-7072. https://doi. org/10.1158/0008-5472.CAN-09-4291

79. Cackowski FC, Anderson JL, Patrene KD, Choksi RJ, Shapiro SD, Windle JJ, Blair HC, Roodman GD (2010) Osteoclasts are important for bone angiogenesis. Blood 115:140-149. https:// doi.org/10.1182/blood-2009-08-237628

80. Endo-Munoz L, Evdokiou A, Saunders NA (2012) The role of osteoclasts and tumour-associated macrophages in osteosarcoma metastasis. Biochim Biophys Acta 1826:434-442. https://doi. org/10.1016/j.bbcan.2012.07.00

81. Perrot P, Rousseau J, Bouffaut AL, Rédini F, Cassagnau E, Deschaseaux F, Heymann MF, Heymann D, Duteille F, Trichet V, Gouin F (2010) Safety concern between autologous fat graft, mesenchymal stem cell and osteosarcoma recurrence. PLoS ONE 5(6):e10999. https://doi.org/10.1371/journal. pone.0010999

82. Cortini M, Massa A, Avnet S, Bonuccelli G, Baldini N (2016) Tumor-Activated Mesenchymal stromal cells promote osteosarcoma stemness and migratory potential via IL-6 secretion. PLoS ONE 11:e0166500. https://doi.org/10.1371/journal. pone. 0166500

83. Massa A, Perut F, Chano T, Woloszyk A, Mitsiadis TA, Avnet S, Baldini N (2017) The effect of extracellular acidosis on the behaviour of mesenchymal stem cells in vitro. Eur Cell Mater 33:252-267. https://doi.org/10.22203/eCM.v033a19

84. Avnet S, Di Pompo G, Chano T, Errani C, Ibrahim-Hashim A, Gillies RJ, Donati DM, Baldini N (2017) Cancer-associated mesenchymal stroma fosters the stemness of osteosarcoma cells in response to intratumoral acidosis via NF- $\mathrm{KB}$ activation. Int $\mathrm{J}$ Cancer 140(6):1331-1345. https://doi.org/10.1002/ijc.30540

85. Tellez-Gabriel M, Charrier C, Brounais-Le Royer B, Mullard M, Brown HK, Verrecchia F, Heymann D (2017) Analysis of gap junctional intercellular communications using a dielectrophoresis-based microchip. Eur J Cell Biol 96:110-118. https://doi. org/10.1016/j.ejcb.2017.01.003

86. Xu H, Gu S, Riquelme MA, Burra S, Callaway D, Cheng H, Guda T, Schmitz J, Fajardo RJ, Werner SL, Zhao H, Shang P, Johnson ML, Bonewald LF, Jiang JX (2015) Connexin 43 channels are essential for normal bone structure and osteocyte viability. $\mathrm{J}$ Bone Miner Res 30:436-448. https://doi.org/10.1002/jbmr.2374

87. Talbot J, Verrecchia F (2012) Gap junctions and bone remodeling. Biol Aujourdhui 206:125-134. https://doi.org/10.1051/ jbio/2012016

88. Plotkin LI, Davis HM, Cisterna BA, Sáez JC (2017) Connexins and pannexins in bone and skeletal muscle. Curr Osteoporos Rep 15:326-334. https://doi.org/10.1007/s11914-017-0374-Z

89. Talbot J, Brion R, Picarda G, Amiaud J, Chesneau J, Bougras G, Stresing V, Tirode F, Heymann D, Redini F, Verrecchia F (2013) Loss of connexin43 expression in Ewing's sarcoma cells favors the development of the primary tumor and the associated bone osteolysis. Biochim Biophys Acta 1832:553-564. https:// doi.org/10.1016/j.bbadis.2013.01.001

90. Torreggiani E, Roncuzzi L, Perut F, Zini N, Baldini N (2016) Multimodal transfer of MDR by exosomes in human osteosarcoma. Int J Oncol 49:189-196. https://doi.org/10.3892/ ijo.2016.3509

91. Baglio SR, Lagerweij T, Pérez-Lanzón M, Ho XD, Léveillé N, Melo SA, Cleton-Jansen AM, Jordanova ES, Roncuzzi L, Greco M, van Eijndhoven MAJ, Grisendi G, Dominici M, Bonafede R, Lougheed SM, de Gruijl TD, Zini N, Cervo S, Steffan A, Canzonieri V, Martson A, Maasalu K, Köks S, Wurdinger T, Baldini N, Pegtel DM (2017) Blocking tumor-educated MSC paracrine activity halts osteosarcoma progression. Clin Cancer Res. https:// doi.org/10.1158/1078-0432.CCR-16-2726 (in press)
92. Heymann D, Ory B, Blanchard F, Heymann MF, Coipeau P, Charrier C, Couillaud S, Thiery JP, Gouin F, Redini F (2005) Enhanced tumor regression and tissue repair when zoledronic acid is combined with ifosfamide in rat osteosarcoma. Bone 37:74-86. https://doi.org/10.1016/j.bone.2005.02.020

93. Karsenty G, Oury F (2010) The central regulation of bone mass, the first link between bone remodeling and energy metabolism. J Clin Endocrinol Metab 95:4795-4801. https://doi.org/10.1210/ jc. $2010-1030$

94. Corr A, Smith J, Baldock P (2017) Neuronal control of bone remodeling. Toxicol Pathol. https://doi. org/10.1177/0192623317738708

95. Dimitri P, Rosen C (2017) The central nervous system and bone metabolism: an evolving story. Calcif Tissue Int 100:476-485. https://doi.org/10.1007/s00223-016-0179-6

96. Kondo A, Mogi M, Koshihara Y, Togari A (2001) Signal transduction system for interleukin- 6 and interleukin-11 synthesis stimulated by epinephrine in human osteoblasts and human osteogenic sarcoma cells. Biochem Pharmacol 61:319-326. https:// doi.org/10.1016/S0006-2952(00)00544-X

97. Broadhead ML, Choong PF, Dass CR (2012) Efficacy of continuously administered PEDF-derived synthetic peptides against osteosarcoma growth and metastasis. J Biomed Biotechnol 2012:230298. https://doi.org/10.1155/2012/230298

98. Punzo F, Tortora C, Di Pinto D, Manzo I, Bellini G, Casale F, Rossi F (2017) Anti-proliferative, pro-apoptotic and anti-invasive effect of EC/EV system in human osteosarcoma. Oncotarget 8:54459-54471. https://doi.org/10.18632/oncotarget.17089

99. Otero JE, Stevens JW, Malandra AE, Fredericks DC, Odgren PR, Buckwalter JA, Morcuende J (2014) Osteoclast inhibition impairs chondrosarcoma growth and bone destruction. J Orthop Res 32:1562-1571. https://doi.org/10.1002/jor.22714

100. Piperno-Neumann S, Le Deley MC, Rédini F, Pacquement H, Marec-Bérard P, Petit P, Brisse H, Lervat C, Gentet JC, EntzWerlé N, Italiano A, Corradini N, Bompas E, Penel N, Tabone MD, Gomez-Brouchet A, Guinebretière JM, Mascard E, Gouin F, Chevance A, Bonnet N, Blay JY, Brugières L, Sarcoma Group of UNICANCER, French Society of Pediatric Oncology (SFCE), French Sarcoma Group (GSF-GETO) (2016) Zoledronate in combination with chemotherapy and surgery to treat osteosarcoma (OS2006): a randomised, multicentre, open-label, phase 3 trial. Lancet Oncol 17:1070-1080. https://doi.org/10.1016/ S1470-2045(16)30096-1

101. Lézot F, Chesneau J, Navet B, Gobin B, Amiaud J, Choi Y, Yagita H, Castaneda B, Berdal A, Mueller CG, Rédini F, Heymann D (2015) Skeletal consequences of RANKL-blocking antibody (IK22-5) injections during growth: mouse strain disparities and synergic effect with zoledronic acid. Bone 73:51-59. https:// doi.org/10.1016/j.bone.2014.12.011

102. Qian BZ, Pollard JW (2010) Macrophage diversity enhances tumor progression and metastasis. Cell 141:39-51. https://doi. org/10.1016/j.cell.2010.03.014

103. Sousa S, Auriola S, Mönkkönen J, Määttä J (2015) Liposome encapsulated zoledronate favours M1-like behaviour in murine macrophages cultured with soluble factors from breast cancer cells. BMC Cancer 15:4. https://doi.org/10.1186/ s12885-015-1005-7

104. Veltman JD, Lambers ME, van Nimwegen M, Hendriks RW, Hoogsteden HC, Hegmans JP, Aerts JG (2010) Zoledronic acid impairs myeloid differentiation to tumour-associated macrophages in mesothelioma. Br J Cancer 103:629-641. https://doi. org/10.1038/sj.bjc.6605814

105. Buddingh EP, Kuijjer ML, Duim RA, Bürger H, Agelopoulos K, Myklebost O, Serra M, Mertens F, Hogendoorn PC, Lankester AC, Cleton-Jansen AM (2011) Tumor-infiltrating macrophages are associated with metastasis suppression in high-grade 
osteosarcoma: a rationale for treatment with macrophage activating agents. Clin Cancer Res 17:2110-2119. https://doi. org/10.1158/1078-0432.CCR-10-2047

106. Dumars C, Ngyuen JM, Gaultier A, Lanel R, Corradini N, Gouin F, Heymann D, Heymann MF (2016) Dysregulation of macrophage polarization is associated with the metastatic process in osteosarcoma. Oncotarget 7:78343-78354. https://doi. org/10.18632/oncotarget.13055

107. Fujiwara T, Fukushi J, Yamamoto S, Matsumoto Y, Setsu N, Oda Y, Yamada H, Okada S, Watari K, Ono M, Kuwano M, Kamura S, Iida K, Okada Y, Koga M, Iwamoto Y (2011) Macrophage infiltration predicts a poor prognosis for human Ewing sarcoma. Am J Pathol 179:1157-1170. https://doi. org/10.1016/j.ajpath.2011.05.03

108. Inagaki Y, Hookway E, Williams KA, Hassan AB, Oppermann U, Tanaka Y, Soilleux E, Athanasou NA (2016) Dendritic and mast cell involvement in the inflammatory response to primary malignant bone tumours. Clin Sarcoma Res 6:13. https://doi. org/10.1186/s13569-016-0053-3

109. Heymann MF, Lezot F, Heymann D. The contribution of immune infiltrates and the local microenvironment in the pathogenesis of osteosarcoma. Cellular Immunol. https://doi. org/10.1016/j.cellimm.2017.10.011 (in press)

110. Théoleyre S, Mori K, Cherrier B, Passuti N, Gouin F, Rédini F, Heymann D (2005) Phenotypic and functional analysis of lymphocytes infiltrating osteolytic tumors: use as a possible therapeutic approach of osteosarcoma. BMC Cancer 5:123. https://doi.org/10.1186/1471-2407-5-123

111. Meftah M, Schult P, Henshaw RM (2013) Long-term results of intralesional curettage and cryosurgery for treatment of lowgrade chondrosarcoma. J Bone Joint Surg Am 95:1358-1364. https://doi.org/10.2106/JBJS.L.00442

112. Riedel RF, Larrier N, Dodd L, Kirsch D, Martinez S, Brigman BE (2009) The clinical management of chondrosarcoma. Curr Treat Options Oncol 10:94-106. https://doi.org/10.1007/ s11864-009-0088-2

113. Heymann MF, Brown HK, Heymann D (2016) Drugs in early clinical development for the treatment of osteosarcoma. Expert Opin Investig Drugs 25:1265-1280. https://doi.org/10.1080/1 3543784.2016.1237503

114. Meyers PA, Schwartz CL, Krailo MD, Healey JH, Bernstein ML, Betcher D, Ferguson WS, Gebhardt MC, Goorin AM, Harris M, Kleinerman E, Link MP, Nadel H, Nieder M, Siegal GP, Weiner MA, Wells RJ, Womer RB, Grier HE. Children's Oncology Group (2008) Osteosarcoma: the addition of muramyl tripeptide to chemotherapy improves overall survival-a report from the Children's Oncology Group. J Clin Oncol 26:633-638. https://doi.org/10.1200/JCO.2008.14.0095

115. Redini F, Odri GA, Picarda G, Gaspar N, Heymann MF, Corradini N, Heymann D (2013) Drugs targeting the bone microenvironment: new therapeutic tools in Ewing's sarcoma? Expert Opin Emerg Drugs 18:339-352. https://doi.org/10.1517/1472 8214.2013.823948

116. Gaspar N, Hawkins DS, Dirksen U, Lewis IJ, Ferrari S, Le Deley MC, Kovar H, Grimer R, Whelan J, Claude L, Delattre O, Paulussen M, Picci P, Sundby Hall K, van den Berg H, Ladenstein R, Michon J, Hjorth L, Judson I, Luksch R, Bernstein ML, Marec-Bérard P, Brennan B, Craft AW, Womer RB, Juergens H, Oberlin O (2015) Ewing sarcoma: current management and future approaches through collaboration. J Clin Oncol 33:3036-3046. https://doi.org/10.1200/JCO.2014.59.5256

117. Xing M, Yan F, Yu S, Shen P (2015) Efficacy and cardiotoxicity of liposomal doxorubicin-based chemotherapy in advanced breast cancer: a meta-analysis of ten randomized trials. PLoS ONE 10:e0133569. https://doi.org/10.1371/journal. pone. 0133569
118. Kang MH, Wang J, Makena MR, Lee JS, Paz N, Hall CP, Song MM, Calderon RI, Cruz RE, Hindle A, Ko W, Fitzgerald JB, Drummond DC, Triche TJ, Reynolds CP (2015) Activity of MM-398, nanoliposomal irinotecan (nal-IRI), in Ewing's family tumor xenografts is associated with high exposure of tumor to drug and high SLFN11 expression. Clin Cancer Res 21:11391150. https://doi.org/10.1158/1078-0432.CCR-14-1882

119. Mitchison TJ (2012) The proliferation rate paradox in antimitotic chemotherapy. Mol Biol Cell 23:1-6. https://doi.org/10.1091/ mbc.E10-04-0335

120. Ségaliny AI, Tellez-Gabriel M, Heymann MF, Heymann D (2015) Receptor tyrosine kinases: characterisation, mechanism of action and therapeutic interests for bone cancers. J Bone Oncol 4:1-12. https://doi.org/10.1016/j.jbo.2015.01.001

121. Heymann D, Rédini F (2013) Targeted therapies for bone sarcomas. BoneKEy Rep 2:378. https://doi.org/10.1038/ bonekey.2013.112

122. Safwat A, Boysen A, Lücke A, Rossen P (2014) Pazopanib in metastatic osteosarcoma: significant clinical response in three consecutive patients. Acta Oncol 53:1451-1454. https://doi.org /10.3109/0284186X.2014.948062

123. Attia S, Okuno SH, Robinson SI, Webber NP, Indelicato DJ, Jones RL, Bagaria SP, Jones RL, Sherman C, Kozak KR, Cortese CM, McFarland T, Trent JC, Maki RG (2015) Clinical activity of pazopanib in metastatic extraosseous Ewing sarcoma. Rare Tumors 7:5992. https://doi.org/10.4081/rt.2015.5992

124. Mross K, Frost A, Steinbild S, Hedbom S, Büchert M, Fasol U, Unger C, Krätzschmar J, Heinig R, Boix O, Christensen O (2012) A phase I dose-escalation study of regorafenib (BAY 73-4506), an inhibitor of oncogenic, angiogenic, and stromal kinases, in patients with advanced solid tumors. Clin Cancer Res 18:26582667. https://doi.org/10.1158/1078-0432

125. Subbiah V, Anderson P, Rohren E (2015) Alpha emitter radium 223 in high-risk osteosarcoma: first clinical evidence of response and blood-brain barrier penetration. JAMA Oncol 1:253-255. https://doi.org/10.1001/jamaoncol.2014.289

126. Garnett MJ, Edelman EJ, Heidorn SJ, Greenman CD, Dastur A, Lau KW, Greninger P, Thompson IR, Luo X, Soares J, Liu Q, Iorio F, Surdez D, Chen L, Milano RJ, Bignell GR, Tam AT, Davies H, Stevenson JA, Barthorpe S, Lutz SR, Kogera F, Lawrence K, McLaren-Douglas A, Mitropoulos X, Mironenko T, Thi H, Richardson L, Zhou W, Jewitt F, Zhang T, O'Brien P, Boisvert JL, Price S, Hur W, Yang W, Deng X, Butler A, Choi HG, Chang JW, Baselga J, Stamenkovic I, Engelman JA, Sharma SV, Delattre O, Saez-Rodriguez J, Gray NS, Settleman J, Futreal PA, Haber DA, Stratton MR, Ramaswamy S, McDermott U, Benes CH (2012) Systematic identification of genomic markers of drug sensitivity in cancer cells. Nature 483:570-575. https:// doi.org/10.1038/nature11005

127. Choy E, Butrynski JE, Harmon DC, Morgan JA, George S, Wagner AJ, D'Adamo D, Cote GM, Flamand Y, Benes CH, Haber DA, Baselga JM, Demetri GD (2014) Phase II study of olaparib in patients with refractory Ewing sarcoma following failure of standard chemotherapy. BMC Cancer 4:813. https://doi. org/10.1186/1471-2407-14-813

128. van Maldegem AM, Bovée JV, Peterse EF, Hogendoorn PC, Gelderblom H (2016) Ewing sarcoma: the clinical relevance of the insulin-like growth factor 1 and the poly-ADP-ribosepolymerase pathway. Eur J Cancer 53:171-180. https://doi. org/10.1016/j.ejca.2015.09.009

129. Alsaab HO, Sau S, Alzhrani R, Tatiparti K, Bhise K, Kashaw SK, Iyer AK (2017) PD-1 and PD-L1 checkpoint signaling inhibition for cancer immunotherapy: mechanism, combinations, and clinical outcome. Front Pharmacol 8:561. https://doi.org/10.3389/ fphar.2017.00561 
130. Pinto N, Park JR, Murphy E, Yearley J, McClanahan T, Annamalai L, Hawkins DS, Rudzinski ER (2017) Patterns of PD-1, PD-L1, and PD-L2 expression in pediatric solid tumors. Pediatr Blood Cancer. https://doi.org/10.1002/pbc.26613

131. Paydas S, Bagir EK, Deveci MA, Gonlusen G (2016) Clinical and prognostic significance of PD-1 and PD-L1 expression in sarcomas. Med Oncol 33:93. https://doi.org/10.1007/ s12032-016-0807-z

132. Shen JK, Cote GM, Choy E, Yang P, Harmon D, Schwab J, Nielsen GP, Chebib I, Ferrone S, Wang X, Wang Y, Mankin H, Hornicek FJ, Duan Z (2014) Programmed cell death ligand 1 expression in osteosarcoma. Cancer Immunol Res 2:690-698. https://doi.org/10.1158/2326-6066.CIR-13-0224

133. Sundara YT, Kostine M, Cleven AH, Bovée JV, Schilham MW, Cleton-Jansen AM (2017) Increased PD-L1 and T-cell infiltration in the presence of HLA class I expression in metastatic high-grade osteosarcoma: a rationale for T-cell-based immunotherapy. Cancer Immunol Immunother 66:119-128. https://doi. org/10.1007/s00262-016-1925-3

134. Paoluzzi L, Cacavio A, Ghesani M, Karambelkar A, Rapkiewicz A, Weber J, Rosen G (2016) Response to anti-PD1 therapy with nivolumab in metastatic sarcomas. Clin Sarcoma Res 6:24. https://doi.org/10.1186/s13569-016-0064-0

135. Dobrenkov K, Ostrovnaya I, Gu J, Cheung IY, Cheung NK (2016) Oncotargets GD2 and GD3 are highly expressed in sarcomas of children, adolescents, and young adults. Pediatr Blood Cancer 63:1780-1785. https://doi.org/10.1002/pbc.26097

136. Bernstein-Molho R, Kollender Y, Issakov J, Bickels J, Dadia S, Flusser G, Meller I, Sagi-Eisenberg R, Merimsky O (2012) Clinical activity of mTOR inhibition in combination with cyclophosphamide in the treatment of recurrent unresectable chondrosarcomas. Cancer Chemother Pharmacol 70:855-860. https://doi. org/10.1007/s00280-012-1968-x

137. Perez J, Decouvelaere AV, Pointecouteau T, Pissaloux D, Michot JP, Besse A, Blay JY, Dutour A (2012) Inhibition of chondrosarcoma growth by mTOR inhibitor in an in vivo syngeneic rat model. PLoS ONE 7:e32458. https://doi.org/10.1371/ journal.pone. 0032458

138. Kostine M, Cleven AH, de Miranda NF, Italiano A, CletonJansen AM, Bovée JV (2016) Analysis of PD-L1, T-cell infiltrate and HLA expression in chondrosarcoma indicates potential for response to immunotherapy specifically in the dedifferentiated subtype. Mod Pathol 29:1028-1037. https://doi.org/10.1038/ modpathol.2016.108

139. Amelio JM, Rockberg J, Hernandez RK et al (2016) Population-based study of giant cell tumor of bone in Sweden (19832011). Cancer Epidemiol 42:82-89. https://doi.org/10.1016/j. canep.2016.03.014

140. Dahlin DC, Cupps RE, Johnson EW Jr (1970) Giant-cell tumor: a study of 195 cases. Cancer 25:1061-1070. https:// doi.org/10.1002/1097-0142(197005)25:5<1061::AIDCNCR2820250509>3.0.CO;2-E

141. Rosario M, Kim HS, Yun JY, Han I (2017) Surveillance for lung metastasis from giant cell tumor of bone. J Surg Oncol. https:// doi.org/10.1002/jso.24739 (in press)

142. Renema N, Navet B, Heymann MF, Lezot F, Heymann D (2016) RANK-RANKL signalling in cancer. Biosci Rep 36(4):e00366. https://doi.org/10.1042/BSR20160150

143. Gouin F, Rochwerger AR, Di Marco A, Rosset P, Bonnevialle P, Fiorenza F, Anract P (2014) Adjuvant treatment with zoledronic acid after extensive curettage for giant cell tumours of bone. Eur J Cancer 50:2425-2431. https://doi.org/10.1016/j. ejca.2014.06.003

144. Chawla S, Henshaw R, Seeger L, Choy E, Blay JY, Ferrari S, Kroep J, Grimer R, Reichardt P, Rutkowski P, Schuetze S, Skubitz K, Staddon A, Thomas D, Qian Y, Jacobs (2013) Safety and efficacy of denosumab for adults and skeletally mature adolescents with giant cell tumour of bone: interim analysis of an openlabel, parallel-group, phase 2 study. Lancet Oncol 14:901-908. https://doi.org/10.1016/S1470-2045(13)70277-8 